7. S. Departinent of Interior: Bureau of Land langement 800 Truxtun Avenue, Room 311 Bakersfiald, CA 93301

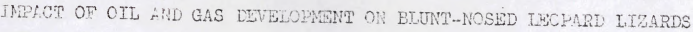

\title{
Finel Report:
}

\author{
Subritted by: David I. Chesemore, Th.D. \\ Depertment of Biclogy \\ Califorwia Staie Thiversity, Fresno \\ Fresuo, Cuitifomia 93740
}

is fultilament of contract V/2-512-Cro-118 


\section{ABSTRACT}

The impact of oil and gas development on blunt-nosed leopard lizards (Gambelia silus) was studied in the southern San Joaquin Valley, California, during May-July 1979. Ecological features on 14 study sites were described. Relative densities of lizards on all 14 sites were estimated and absolute densities on 5 intensive study sites were determined. Increased oil and gas development decreased the number of lizards present on a site. Uta stansburiana abundance was positively correlated with increasing disturbance of the habitat but Cnemidophorus tigris numbers showed no relationship to the level of development. No inverse relationship between Gambelia and Cnemidophorus numbers was indicated by the relative density estimates. The type of roads and the suitability of the habitat for lizards may determine whether or not blunt-nosed leopard lizards concentrate near roadways. Washes appear to be critical corridors of habitat for Gambelia and other wildlife. Schismus arabicus abundance was positively correlated with Gambelia abundance so this grass may serve as a setisfactory indicator of habitat suitability for the blunt-nosed leopard lizard. The mathematical equation that best estimated absolute density of blunt-nosed leopard lizards from relative density estimates was: $\log Y=-0.0561+0.778 \log X \quad(r=.994)$. Formulas for prodiction of absolute density of blunt-nosed leopard lizards from relative density estimates are given. Detailed suggestions for wash management are given and additional information needed to adequately manage habitats for Gambelia are also discussed. 
INTRODUCTION. .1 OBJECTIVES OF THE STUDY. .2 METHODS

Determination of Relative Densities of Lizards.............

Determination of Absolute Denity of Lizards...............

Mathematical Relationships Between Densities.............

Description of Elunt-nosed Leopard Lizard Habitats..........

Description of Intensive Study Sites.................

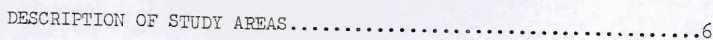

Vegetation of the Study Sites $\ldots \ldots \ldots \ldots \ldots \ldots \ldots \ldots \ldots \ldots \ldots$ ?

Soils of the study sites.........................

Vertebrates Present on the Study Sites................ DESCRIPTIONS OF INDIVIDUAL STUDY SITES. $\ldots \ldots \ldots \ldots \ldots \ldots \ldots \ldots$ RESULTS.

Relative Density Estimates of Lizards................. 15

Absolute Density Estimates of Blunt--nosed Leopard Lizards...16

Correlation Between Relative and Absolute Density Eistimates..15

Prediction of Absolute Density from Relative Density Data... 17

Density of Animal Burrows on Intensive Study Sites......... 18

Correlation of Environmental Conditions and Lizard Density...19 DISCUSSION OF THE RESULTS. . . . . . . . . . . . . . . . 19

Impact of Development on Gambelia.....................

Impact of Roads on Blunt-nosed Leopard Lizard Density.......21

Impact of Washes on Blunt-nosed Leopard Lizard Abundance....23 
Relationship of Schismus arabicus to Gambelia Abundance.....24 Interactions of Gambelia and Cnemidophorus ...............

Modification of the Cruise Method....................... 25

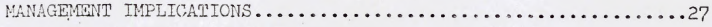

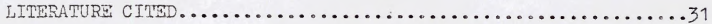
APEENDIX 1. Example of Data Recording Form for Burrows.......59 APPANDIX 2. Transect Method of Community Description........60 


\section{LIST OF TABLES}

Table

1. General description of the 14 study sites utilized to determine the impact of oil and gas development on blunt-nosed leopard lizards in the southern San Joaquin Valley, California.

2. Vascular plants present on the 14 study sites used to determine the impact of oil and gas development on the blunt-nosed leopard lizard in the southern San Joaquin

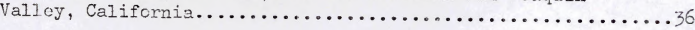

3. Vascular plants considered to be reliable indicators of disturbed habitat near Taft, California................. 39

4. Composition of vascular vegetation on intensive study site number 1 , near Taft, California..................

5. Composition of vascular vegetation on intensive study site number 2, near Taft, California.....................

6. Composition of vascular vegetation on intensive study site number 3 , near Taft, California....................

7. Conposition of vascular vegetation on intensive study site number 4 , near Taft, California......................... 44

8. Composition of vascular vegetation on intensive study site number 5 , near Taft, California.................... 45

9. Texture and bulk density of soils on study sites 1-5 near

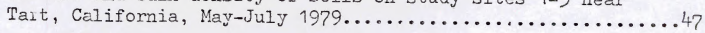

10. Vertebrates present on the 14 study sites used to determine the impact of oil and gas development on the blunt-nosed leopard lizard in the southerr San Joaquin Valley, California, May-July 1979.

11. Relative densities of lizards on 14 study sites near Taft, California, during June-July 1979, based on transect counts...53

12. Estimates of average relative densities and absolute densities of blunt-nosed leopard lizards on intensive study sites 1-5 near Taft, California, during May-July $1979 \ldots \ldots \ldots \ldots \ldots \ldots 5$

13. Density of animal burrows on intersive study sites 1-5 near

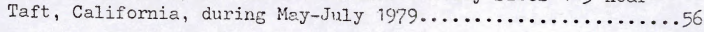

1'. Correlation coefficients (Spearmans rho) for relative densities of lizards and environmenta] conditions on 14 study sites near Taft, Califormia, May-July 1979 .......... 5 ? 


\section{INIRODUCTION}

The endangered status of the blunt-nosed leopard lizard Gambelia Si:us) is due primarily, if not exclusively, to the loss or drastic modification of its habitat. Because many of these remaining lizard Wornlations occur on public lands subject to development for oil and ratural gas, a basic understanding of lizard ecology and its reaction to various levels of development is needed. Once their biological needs are known, realistic management plans can be implemented. This action will ensure the minimum adverse impact of such developments. To provide this essential information for such management, this study was designed to examine the impact of different Ievels of oil and gas development on blunt-nosed leopard lizards in and about the Southern San Joaquin Valley (Fig. 1). This study was carried out between 22 Hay and 1 August 1979.

Information on the distribution, abundance and natural history of the blunt-nosed leopard lizard has been compiled primarily by Montanucci $(1965,1967,1968,1970,1978 \mathrm{a}, 1978 \mathrm{~b})$, Bury (1971), and Fisk (1972). Snow (1972) has summarized the fublished literature on the blunt-nosed leopard lizard for the U.S. Bureau of Land Management. Tollestrup (1976) has provided some information on this lizard's ecolosy but much of her information is still unavailable, since it is part of a dissertation that is not yet available to the general public.

Financial support for this study was provided through the U.S. Bureau of Land Management (BLM), Contract YA-512-CT9-118 and administered through the Bakersfield District Office. Fieldwork for 
the project was done by: Tom Campbell, Pat Gordon, Bill Clark, Bob Hansen, Jennifer Babcock, and Steve Juarez.

\section{$\cdot \quad$ OBJECTIVES OF THE STUDY}

The objectives of this study were:

(1) to determine the relative abundance of blunt-nosed leopard lizards on 14 study sites in the southern San Joaquin Valley;

(2) to describe qualitatively and quantitatively the habitat characteristics of 5 intensive study areas with particular detail allotted to vegetation, soil conditions, amount of oil and gas development and activity, and the density of rodent burrows;

(3) to provide species lists of other wildlife, particularily vertebrates and rare or endengered species of vascular plants found on the sites;

(4) to determine the absolute abundance (density per unit area) of leopard lizards on 5 intensive study sites;

(5) to establish the mathematical relationship between relative density and absolute density estimates on the intensive study sites and place measures of statistical reliability around such estimates;

(6) to provide correlation coefficients for dominant species of vascular plants and the level of oil and gas development and to determine if any of the vascular plants could be used as indicators of blunt-nosed leopard lizard habitat; and

(7) to propose management recommendations based on various levels of oil and gas development so that current levels of blunt-nosed leopard lizards can be maintained or increased. 
METHODS

Determination of Relative Densities of Blunt-nosed Leovard Lizards

Relative density estimates were based on the cruise method described by Tollestrup (1976). Sixteen equally spaced survey lines on a 20 acre study plot were used to collect the relative density estimates. In order to minimize differences between observers, the relative density cruises were done by the same person with their assigument to a particular site selected at random. Survey sites were slightly rectangular and survey flags were placed at $15-25 \mathrm{~m}$ intervals along the travel routes to aid the investigator in maintaining repeatable transect routes. Hand compasses were used when needed. Each sample site was oriented with its short axis in a north-south direction to minimize vieving problems of an investigator having to look directly into the sun during a portion of the survey. All. observations from the transect were recorded on a standard data sheet (Appendix 1).

Determination of Absolute Density of Blunt-nosed Leoperd Lizards

Systematic search of each intensive study area and capture and marking of leopard lizards seen on the site provided the basis for the absolute density estimates. Lizards were captured ("noosed") with sliding nooses on poles (Brown and Alcala 1961). Captured lizards were permanently maxked by toe-clipping (Stebbins 1966) and an individual number painted on the side of each animal so that it could be identified later without handling. The exact location of capture was marked on a map of the study area. Subsequent sightings were recorded on the same map. 
Population densities were computed using the Lincoln Index (Giles 1969). Periodic total counts were done by several investigators on each intensive study site to provide another form of estimate of lizard numbers.

Mathematical Relationships Between Relative ard Absolute Densities

Once relative densities and estimates of absolute density were obtained for each intensive study site, a regression analysis was performed to determine if any reliable relationship existed between these two measures ( $\operatorname{Zar} 1974$ ).

Descrivtion of Blunt-nosed Leopard Lizard Habitats

Outline maps of the 5 intensive study sites were constructed from aerial photographs. Distinctive lendmarks were noted on each map. The degree of oil and gas development was determined from the aerial photograph and verified by ground search of the site. Each of the 14 study sites was described in general terms as to elevation, topography, vegetation type, and level of development. Species lists of vascular plants, mamnals, birds, reptiles, and amphibians were compiled for each site.

All study sites were photographed with $35 \mathrm{mn}$ black and white film to provide a permanent, visual record of conditions as they existed on each site at the time of the study. Color slides were also taken of the intensive study areas.

Description of Intensive Study Sites 
Detailed habitat descriptions were made for each of the 5 intensive study sites. During both the initial investigation and the cruise surveys for relative abundance, the exact location of each leopard lizard was marked with survey stakes. Each of these locations served as a potential sampling point for the vegetation and soils work.

Five composite soil samples were taken at randomly selected survey stakes, as described above, in each intensive study area. If no leopard lizards occurred within the study sites, then samples were drawn randomly from the entire unit. The sample included the upper $30 \mathrm{~cm}$ of the soil and was stored in plastic bags until analyzed at the Soils Laboratory, California State University, Fresno. The texture of the soil was determined by mechanical analysis with the Bouyoucos hydrometer method (Bouyoucos 1936). Bulk density of the soil was measured by taking an undisturbed block of soil, determining its volume, drying it, and weighing it (Donahue et al. 1974:62). Bulk density indicates the degree of compaction of the soil and may help explain the existing pattern of lizard abundance on the study area. The occurrence and extent of soil erosion present on the study sites was documented. Slope and elevation on each study site was determined from U.S. Geological Survey maps.

Vegetation was quantified utilizing the line-intercept procedure (Canfield 1941, Mueller-Dombois and Ellenberg 1974). The line-intercept extended $25 \mathrm{~m}$ on either side of a randomly selected survey stake and was positioned by selecting a random azimuth for $25 \mathrm{~m}$ of the survey line and then $25 \mathrm{~m}$ along the backsight ( $180^{\circ}$ from the first azimuth). Voucher specimens of vascular plants were collected and verified at the 
Herbarium, California State University, Fresno. Standard descriptive statistics for the line-intercept resul.ts were then calculated (Phillips 1959). These formulas are show in Appendix 2.

Density of animal burrows was determined using the point-quarter technique (Curtis and McIntosh 1951, Ashby 1972). Twenty-five randomly located points were selected along the $50 \mathrm{~m}$ line used to sample vegetation and the distance to the nearest animal burrow or suitable underground shelter for a blunt-nosed leopard lizard was measured.

These habitat data proviced the quantitative bases for the calculation of correlation coefficients between environmental features and lizard numbers. Spearman's rho correlation coefficients were calculated for each of these comparisons ( $\operatorname{ar} 1974$ ).

\section{DESCRIPTION OF STUDY AREAS}

Fourteen study sites were utilized during this work with sites 1-5 being the interisive study sites on which both absolute and relative density estimates for the blunt-nosed leopard lizards were collected (Table 1). Considerable variation in ecological conditions and past historical use occurred within the study sites.

The current status of each study site, based on pas and present development of oil and gas reserves and other human usage was reported as follows:

(1)-no development of oil and gas reserves and no human disturbance on the site;

(2)-no current, modern-day development for oil and gas reserves although evidence of old development present, no modern, 
active roads through the site;

(3)-light to moderate development for oil and gas production with few (1-5) oil and gas wells or structures present on the site, 1 or 2 lightly used roads present on the study site;

(4)-considerable development on the site for oil and gas production with 5-10 oil and gas wells or structures present on the site, some native vegetation remaining between oil structures with several roads within the site having light to moderately heavy vehicle traffic; and

(5)-extremely heavy development and daily activity on many roads, virtually no native vegetation left on the site, and more than 10 oil and gas production structures currently operating within the site.

\section{Vegetation of the Study Sites}

During fieldwork on the study sites, vascular plants were collected and identified to provide a general idea of the presence of common species within the area (Table 2). Nine species of vascular plants were considered to serve as indicators of disturbance (Table 3). These plants were growing commonly on recently disturbed sites and/or were mentioned in the literature as being indicators of disturbed habitats.

Quantitative data on the plant communities in the intensive study sites 1-5 was collected with line-intercept sanpling. Estimates of percent of bare ground, percent of cover per species, frequency per species, relative dominance; relative frequency, and importance value per species are presented in Tables 4-8. 
Soils of the Study Sites

The results of the soils analyses are presented in Table 9 . Texture analysis was determined for 25 samples and compaction (bulk density.). was determined for 25 samples, with 5 samples veing taken on each intensive study site.

Vertebrates Present on the Study Sites

During fieldwork on and around the 14 study sites vertebrates which were observed were noted and species lists were compiled for each site (Table 10). Five species of lizards, 6 species of snakes, 28 species of birds, and 11 species of mammals were found on or near these study sites.

\section{DESCRIPTIONS OF INDIVIDUAL STUDY SITES}

Site 1

This study area consisted primarily of Bromus-Schismus grassland with scattered clumps of Atriplex on fairly flat terrain (Figs. 2 and 3). Grass cuver is heavy with very few open areas that might serve as foraging or basking areas for leopard lizards. All. Gambelia seen were in or immediately adjacent to one of the two small washes that traversed this plot. All lizard species were localized in these "corridors" of favorable habitat. Gambelia, Uta, and Cnemidorhorus were common in these washes and an occasional Sceloporus magister was was also seen here. There was little or no disturbance on this site so it was given a level of development ranking of 1. 


\section{Site?}

This site possesses fairly level terrain and is heavily grown to dense Bromis grassland and Atriplex (Figs. 4 and 5). Grass cover was very heavy and there were few open patches of ground. Lizard density for all species was very low. A.ll Uta, Cnemidophorus, and the single Gambelia were seen near the dirt roads that traversed the area. Man-caused disturbance is minimal on this site although a portion of it showed evidence of recent recreational molorcycle activity. It was given a level of development ranking of 2 .

Site 3

This study site lay in a heavily developed, rank 5, oil field near the western base of the Temblor Range (Figs. 6 and 7). The terrain varies from flat to moderate inclines. Little of the original annual grasses and Atriplex remains. The area represented the heaviest development found on any of the intensive study areas. There was considerable mechanical surface disturbance on the site. Only Uta a:d Cnemidophorus were observed on this area.

Site 4

This study site lies at the eastern base of the Buena Vista Hills and had a very gentle, but noticeable, rolling slope (Figs. 8 and 9). This area had the highest Gambelia density of the 5 intensive study sites. While there were considerable amounts of heavy cover (Bromus, Schismus), there were also numerous open patches as well as several now-abandoned roads and oil, well platforms that provided basking and foraging openings for lizards. Large bushes (Atrinlex, Isomeris) were numerous and widespread; these provided escape cover for the lizards. 
Grass cover in 1979 , as reported by local residents, appeared denser than is usual. If such is the case, then this site may be even more favorable as Gambelia habitat in the "normal" years when less moisture is available and grass production is consequently less. This site was given a level of development ranking of 2 .

\section{Site 5}

This study site in the Midway Oil Field has been developed rather heavily for oil production so it was given a rank of 4 (Figs. 10 and 11). There has been considerable alteration of natural vegetation, which consisted of Bromus-Schismus grassland with scattered bushes (Atriplex, Hymenoclea). Frequently used dirt roads are present and active oil wells were scattered throughout the site. Although there was a large amount of open space here, these areas were the result of severe surface disturbance of oil development rather than of natural occurrence. Additionally, oil seeps from the wells are present which served as death traps for small rodents, rabbits, birds, and probably lizards as well (Figs. 12 and 13). None of these seeps were fenced to exclude entry by wildlife.

Lizard density cn this plot was quite low. While Ita and Cnemidophorus were present, Gambelia were not seen on the site. This plot was not bordered by undisturbed habitat that might colonize the disturbed area with new lizards. Site 6

This plot was gently sloping from south to north. There was a road running through the southwestern corner of the site and on the south bcundary an oil well. wes located just off of the plot. The site had $40+\mathrm{cm}$ tal.1 grasis and very dense grass cover on about $35 \%$ of the 
plot. Shrubs covered approximately 10\% of the plot. Salsola kali var. tenuifolia was the predominate shrub, though some Atriplex polycarpa were present. Salsola was concentrated in large patches and in a small wash that was $2-3 \mathrm{~m}$ wide. The wash accounted for about $1 \%$ of the plot. Atriplex was fairly evenly distributed throughout the study site (Fig. 14).

There were some small clearings within the site and a road that covered about $2 \%$ of the plot. Rodent burrows were common within the site but were grouped rather than being evenly distributed over the entire area. One Gambelia was found killed on a road about $50 \mathrm{~m}$ east of the study site but it was the only indication of this species in the area as no Gambelia were seen on this study site.

Site?

This plot was flat except for a rise just north of the wash and the wash itself (Figs. 15 and 16). The wash was approximately $5 \mathrm{~m}$ deep and 35-45 $\mathrm{m}$ wide. Grass on the site was $40+\mathrm{cm}$ tall and very dense. The percentage of grass cover was approximately $60 \%$ with the remainder of the area consisting of the large wash, a clearine, and shrubs. The dominant shrub on the site was Atriplex polycarpa which covered about 5\% of the plot. It was evenly disiributed throughout it.

Clearings were small and sparse; although there was one large opening about $140 \mathrm{~m}$ long and $55 \mathrm{~m}$ wide on the plot. This clearing was artificially made by some kind of mechanical scraper. It had few rodent burrows and no vegetative cover. There were a number of rodent burrows within the wash. One adult female blunt-nosed leopard lizard was observed in the vicinity but this lizard was $2 \mathrm{~m}$ outside the study site 
12.

boundary. She was gravid so there were also male lizards in the general area. Site 8

This site was mostly flat and covered with dense, $20+\mathrm{cm}$ tall Bromus rubens (Fig. 17). The only exceptions were the roads and areas approximately $3 \mathrm{~m}$ in diameter that were covered with a dense growth of Erodium. These Erodium mats occurred in 5 or 6 areas on the plot. The roadway traversed the extreme northeastern corner of the plot. It was on this road that the only two leopard lizard sightings were made. One Cnemidophorus was observed just on the plot midway along its northern border. No other lizards were observed on this study site. Site 9

At first glance, this plot appreared to represent favorable habitat for leopard lizards. Site number 2 across the road was found to have at least 2 leopard lizards but none were observed on or near this plot at any time during the study (Fig. 18). Uta and Cnemidoplurus were seen on the study site. Site 9 had extensive open areas and 2 wash systems within it. However, upon closer examination of the open areas, it was.discovered that these areas were found to be the result of previous oil pumpins operations, dirt bikers, and other disturbance. The largest wash was literally paved with dried oil spills, up to 0.6 ? $m$ in thickness. Several active oil seeps contained many species of vertebrates including Uta. Considerable erosion existed on the site and the creeks were subject to flash flooding during seasonal rainstorms. Few rodent burrows occurred in this greatly disturbed wash system. In contrast, the other wash system was not paved with dried oil and contained numerous rodent burrows. 
Site 10

This site, located at the base of the Panorama Hills in the Elkhorn Plain, was at a much higher elevation, $767 \mathrm{~m}$, than any of the other study plots (Fig. 19). It was characterized by mostly flat terrain with the western half of the site in annual grassland (Bromus, Schismus) sparsely covering the ground and interspersed with many open areas. The eastern half of the plot was grown to Atriplex and Ephedra interspersed with annual grasses.

Lizard density was quite high here; Gambelia density probably exceeded that of any of the other plots and Uta and Cnemidophorus were also very common on the area. Phrynosoma coronatum was also observed here.

Although there had been no oil development here, the area has been heavily grazed by cattle and some trampling of vegetation was evident. A little-traveled dirt road bisected the plot from north to south. Site 11

The terrain of this site wes essentially flat with a few low knolls scattered within the site. At the time of the study there was one oil well producing on the plot (Fig. 20). Two additional wells were located within $50 \mathrm{~m}$ of the study site; one to the southeast and one to the north. There was also some evidence of previous development on the site in the form of concrete slabs. Four roads crossing the area had extensive vehicle use occuring during the study. The area was also used by sport hunters.

Two of the 3 Gambelia observations were near roadcuts and Atriplex 20lycarpa bushes. The third was seen in a erassy area approximately $30 \mathrm{~cm}$ from a bald area ringed with Atrivlex. 
The dominant vegetation was Atriplex polycaroa with an understory of Bromus rubens. The bulk of the study site was composed of dense Bromus rubens. Only Cnemidophorus were found in such dense grassy areas.

Site 12

This plot seemed to be the ideal lizard habitat. Although there were several abandoned oil wells on the site, there vere no active wells and no traveled rouds, so the area was almost undisturbed on a daily basis (Fig. 21). Bromus rubens was quite high and thick in spots. However, the amount of bare ground, in the form of large, debrislittered clearings, mostly abandoned oil wells, and one very large wash, still comprised about $50 \%$ of the area. of the study site. It was in these clear areas that lizards were usually, seell. Rodent burrows were rather abundant on the site and several San. Joaquin kit fox dens were found within the study plot. Atriplex polycarpa was the dominart shrub on the plot, and in places, was quite abundant. No Gambelia were seen on the site although many Uta and Cnemidophorus were consistently seen during the transects. Site 13

This siudy site was located north of the town of McKittrick east of Highway 58 directly southeast and across the highway from intensive study site 1. At the time of this study there was no active oil and gas development on the site. However, at the southern boundary of the study site there was evidence of a previous structure. There were no roads in the plot although a dirt road ran parallel to the northern border of the site. This road was used as a dump site for approximately $30 \mathrm{~m}$ from its junction with Highway 58. 
The terrain consisted of low rolling hills in 3 series running north-south through the site. The westernmost wash was sandy-bottomed; the eastern one was choked with Bromus rubens and Salsola kali. The vegetation was essentially the same as that of intensive study site 1 with the exception of 2 bald areas and the westernmost wash of site 13 was covered with dense Bromus rubens. Gambelia was observed only once on site 13 in a bald area near clumps of Atriplex. Site 14

The terrain of the plot was generally level. A small dirt road traversed the plot and a large, open wash ran along and intersected the southern border of the plot. Another small wash branched repeatedly into smaller washes through the center of the plot (Fig. 23). A moderate amount of open area existed adjacent to the washes and throughout the plot's grassy areas. There were a large number of woody shrubs: Atriplex polycarpa, Hymenoclea salsola, Isomeris arborea, and Salsola kali on the site. Rodent burrows were present throughout the plot although more concentrated in washes and their adjacent borks. Some human disturbance in the form of motorcycle travel was present on the site. At least 6 Gambelia, 4 males and 2 femeles, were observed on this study site.

\section{RESULTS}

Relative Density Estimates of Lizards

During May-July 1979, 165 cruise transects (Tollestrup 1976) were run on 14 study sites near Taft, California (Table 11). No blunt-nosed leopard lizards were seen on 6 of the 14 study sites: 3,5,6,7,9, and 12. Site 10 had the ereatest average number of leopard lizurdis seen 

both relative and absolute density estimates must be obtained from at least 3 study sites (Table 11). The mathematical relationship between relative and absolute density can then be determined using a regression analysis (Zar 1974).

This analysis, using the number of lizards marked (X) against the average relative density estimate $(\mathrm{Y})$, produced the predictive equation:

$$
\mathrm{Y}=0.06+0.16 \mathrm{X} \text {. }
$$

The standard error of the estimate $(Y)$ was fairly low $(S E=0.17)$. The correlation between these two sets of data was high $(r=.98)$.

\section{Prediction of Absolute Density from Relative Density Data}

Inverse prediction, the procedure by which the value of the independent variable $\left(x_{i}\right)$ is estimated from some dependent variable $\left(Y_{i}\right)$ has been treated clearly by $\operatorname{Zar}(1974: 213-214)$. By algebraic rearrangement of the linear regression equation $Y=a+b X$, the equation:

$$
X_{i}=\frac{Y_{i}-a}{b}
$$

provides the equation to use in obtaining an absolute density $\left(\mathrm{x}_{i}\right)$ estimate based on relative density estimate $\left(Y_{i}\right)$.

A plot of the residuals of this predictive equation $\left(Y_{i}-\bar{Y}\right)$ results in a heteroscedastic scatter; therefore a logrithmic transformation on both the midpoint and number of lizards marked, after deleting the zero values, resulted in the better equation:

$$
\log Y=-0.0561+0.778 \log X .
$$

The standard error of the estimate ( $Y$ ) was 0.065 . The correlation 
between these two sets of data was very high $(r=.994)$ so the transformation improved the fit of the estimate of absolute density based on the relative density estimates.

The $\log$ of the midpoint seems to be the best overall since it represents a more realistic estimate of the true density. The log transformation of the number of narked lizards results in a better statistical fit, but it is fairly certain that it underestimates the number of lizards present, at least on the plots with lizards present, as all Gambelia probably were not captured and marked on any one site during this study or perhaps during any other such study.

Absolute density can be estimated from relative density using the cruise technique of Tollestrup (1976), with the following equation:

$$
X=\operatorname{antilog} \quad\left[\frac{\log y+0.901}{0.938}\right]
$$

An example of this calculation would be as follows, assuming 5 blunt-nosed leopard lizards were seen on a plot:

$$
X=\operatorname{antilog} \quad\left[\frac{105(5)+0.901}{0.938}\right]
$$

$\mathrm{X}=51$ blunt-nosed leopard lizards actually living on the plot.

Density of Animal Burrows on Intensive Study Sites

The point-quarter method of estimating tree density was used to obtain estimates of the number of animal burrows per hectare on the 5 intensive study sites (Table 13). Considerable variation existed between and within sites on which these estimates were made. The number of burrows per hectare ranged from 16 to 203 . 
Correlation of Environmental Conditions and Iizard Relative Densities

The correlation between relative densities of the 3 predominant species of lizards on the 14 study sites and environmental conditions on the sites were calculated (Table 14). Spearman's rho provided a consistent statistical measure for establishing the strength of these relationships. Its value ranged from -1.0 for perfectly negatively correlated data to +1.0 for perfectly positively correlated data.

\section{DISCUSSION OF THE RESUITS}

The 14 study sites provided a spectrum of habitats for blunt-nosed leopard lizards. The habitats varied from very suitable, as on sites 4 and 10 , and perhaps 1 , to totally unsuitable, such as on site 3 . Detailed environmental measurements, such as percent of bare ground and number of animal burrows per hectare, were estimated for only the 5 intensively studied areas. This small sample size prevented some of the correlations from being statisticall, significant. However, potential biological significance of some of these factors is suggested by trends shown by some of the data as well as the correlation coefficients themselves.

\section{Impact of Development on Gambelia}

It is clear from the data collected on the 5 intensive study sites that high levels of development, use ranking of 5 , such as occurred on site 3, destroy the suitable Gambelia habitat within that area. If the level of development as shown by that on site 3 is projected for all plots containing Gambelia then the fate of the blunt-nosed lecpard lizard on these plots is extinction. It was also clearly shown 
that a site, number 4 , in the Taft area that had once been producing oil and gas but is no longer doing so can support a dense Gambelia population.

The lack of oil and gas development does not assure an abundance of blunt-nosed leopard lizards. Three of the study sites, 7,8, and 13, had no or very few blunt-nosed leopard lizards present even though no oil and gas development existed on these sites. The habitat requirements of Gambelia must be met on a site before it can exist in the area.

It is possible to have some oil and gas production on a site and still maintain a viable population of Gambelia. After oil development ceases, the remaining lizards can recolonize the other areas of the site if conditions become suitable for their existence. The Gambelia population on site 4 is an example of this response. .

Detailed data are lacking on the home range and seasonal movements of lizards within the type of habitat that occurs near Taft. Once these data are available, we will be able to judge whether the disturbed areas will be recolonized from surrounding areas that have viable lizard populations. If this distance is too great, blunt-nosed leopard lizards may never reoccupy the area without being physically moved by man from areas where they exist. into these vacant habitats.

One problem associated with oil production is the leakage of oil from wells, transport pipes, and storage facilities (Fig. 12). The oil seeps associated with production must be prevented through improved oil field maintenance and inspections which are frequent enough to ensure that such equipment is properly working. Dumping of waste oil into washes, such as was observed during this study on site 3 , 
must be prevented by a higher degree of cooperation and understanding between oil and gas producer and the land management agency.

Impact of Roads on Blunt-nosed Leopard Lizard Density

Considerable discussion among biologists exists as to the importance of "roads" and even "open areas" to maintaining or expanding lizard numbers on a site. The obvious question, which has not yet been answered, is do we see more lizards along roads or in open areas because: (1) we see more lizards here because viewing conditions allow us to see more; (2) lizards prefer these roads or open areas as they provide food sources, basking areas, or some other aspect of thein habitat requirements; or (3) it is some combination of (1) and (2) that best answers our original question.

Prior to assessing the impact that roads may have on Gambelia densities, it is necessary to distinquish between different kinds of roads. First, there are roads, mostly prved, that receive moderate to heavy amounts of vehicular traffic. Another road type is the dirt surface type that receives light to moderate amounts of traffic. Waste oil may be periodically applied to it to reduce dust problems. The third type of road is one that has been largely abandoned, either paved or dirt surface, and receives only very light traffic, primarily from recreationalists.

Lizards were frequently signted on the third type of road such as occurred in site 4 . Observations made during fieldwork suggest that - in areas of heavy grass, which is generally unsuitable Gambelia habitat, the presence of narrow, abandoned roads probably serves to concentrate the lizards and serves as an important component of their 
habitat. Rodent burrows were often concentrated along the roadbeds, particularily those with slightly raised banks. Rodent burrows, bushes growing at the road's edge, open areas, and the road's surface, probably attract leopard lizards for basking and foraging. Details of their food habits in these habitats are lacking. The production of favored food types may in large part determine where lizards do well and this aspect of their natural history needs to be investigated further.

If the habitat is especially good for Gambelia, as at site 10 , lizards may not concentrate along the roadway. A small, littletraveled road bisected study site 10. Despite its presence and a high, if not the highest density of Gambelia of all of the study sites, no leopard lizards were sighted on the road during the study. In areas such as study site 10, where an abundance of open areas already existed, roads probably had a negligible effect on the density of leopard lizards present in the area.

While roads may enhance lizard visibility to some extent, it appears that Gambelia nay in fact be concentrated along roadways in some habitats. With tjpe (1) or (2) roads, some mortality from road kills would be expected. One management suggestion is to restrict vehicular traffic as much as possible on these routes or to schedule traffic such that it occurs diring periods of low lizard activity.

Maintenance of existing openings in the area and the artificiai establishment of openings simulatirg the "natural" openings, such as those found on study site 4 or 10 , in areas that have very dense stands of veretation may make these sites more favorable to lizards. 
Fifteen to $30 \%$ bare ground on a site may provide the optimum range of openness for blunt-nosed leopard lizards (Table 14). Many Gambelia occurred on site 4 which had about $28 \%$ of its area in bare ground. After this percentage of open space was reached, lizard numbers declined. A site with $50 \%$ or more open ground may not be suitable for blunt-nosed leopard lizards.

Impact of Washes on Blunt-nosed Leopard Lizard Abundance

The presence of washes appears to be a critical feature for the well-being of blunt-nosed leopard lizards. These corridors of favorable habitat contained most, if not all, of the lizards encountered during the study. Other washes investigated in the general area of Taft often had high numbers of lizards in and immediately adjacent to their edges. Large, natural washes may have several Gambelia within a few hundred meters of wash habitat. Washes that have been subjected to extensive human disturbance, such as pollution with waste oil, vehicular traffic, and clearing of woody shrubs to the edge of their banks, had few or no lizards.

If washes exist on sites that are to be deveioped for oil and gas production, they must be protected and maintained in their natural condition. It is from these populations that recolonizing leopard lizards will probably come to repopulate other areas of the site after disturbance is reduced or ceases.

A 5 to $10 \mathrm{~m}$ wide band of undisturbed vegetation should be maintained on each side of a wash system. No velicular traffic should be allowed in the wash itself and vehicular crossings of the wash 
should be minimized and probably should not be allowed at intervals of more than $1 \mathrm{~km}$. No waste oil should be dumped into the wash. This seems to be the practice now or in the recent past in many of the washes in the Taft area. Dumping of other refuse into these washes should also not be allowed.

These washes constitute "islands" of favorable habitat for a wide variety of wildlife besides Gambelia. These washes need to be intensively studied so that we can obtain a more precise understanding of the impact of disturbances upon their biology. Once this information is known, more. specific guidelines for usage of lands surrounding washes can be formulated.

Relationship of Schismus arabicus to Gambelia abundance

Many biologists conclude dense vegetation is unfavorable habitat for Cambelia. A strong, positive correlation $(.10>p>.05)$ between Schismus arabicus and blunt-nosed leopard lizards was evident (Table 14). There was no significant relationship between Gambelia and Bromus rubens density. Schismus arabicus is a much shorter, sparser grase than Bromus rubens. The two do grow together but often Schismus becomes more abundant in drier years while Bromus rubens becomes less abundant. Moisture conditions in 1979 favored heavy growths of Bromus rubens in the Taft area which may not be typical of the normal relationship between the abundance of these two grasses. Schismus arabicus may open up the habitat to make it more favorable for Gambelia. In the Taft area, more Schismus arabicus on a site may indicate better habitat for blunt-nosed leopard lizards. The relationship between vegetation and food sources, especially insect populations, 
may be of critical importance here.

\section{Interactions of Gambelia and Cnemidophorus}

Montanucci (1965:281) found that Cnemidonhorus was the only lizard which competed with Gambelia; where large numbers of leopard lizards were present, Cnemidophorus were either reduced in numbers or absent. Hie could not determine the exact cause of this inverse relationship between the two species.

Data collected during this study did not support this idea of an inverse relationship of numbers between these two species. In comparing relative densities of these two species on the 14 study sites, a significant, positive correlation $(.01<\mathrm{p}<.05)$ between Gambelia and Cnemidophorus relative densities was indicated.

The exact spatial distribution of these two species may be the source of this apparent contradiction if Gambelia occupy primarily the washes and the Cnemidophorus occupy the grassland areas.

Determination of these species interaction was not one of the objectives of the study but should be included in future studies of Gambelia.

This interaction may determine the success of re-introductions of Gambelia into new habitats.

\section{Modification of the Cruise Method}

This technique developed by Tollestrup (1976) attempts to provide a quick and easy estimate of relative abundance of lizards and wildife along a predetermined route. We suggest that data should be collected along both the $160 \mathrm{~m}$ line and the $1.6 \mathrm{~km}$ "end walks" to the next cruise line. If this is used, the "end walk" would be included and 
data collection would be more efficient.

Two-person teams would also be more effective in both observing and capturing lizards. Capture by standard technique of noosing is possible but difficult. Frequently, these efforts are facilitated by having one person distract the lizard while the second person approaches slowly and nooses the lizard. Two-person teams should also be used for collection of relative density estimates. Particularily in dense cover, a lizard usually only has to move a few $\mathrm{cm}$ to screen itself from an approaching observer and with the second observer moving parallel to the first, a much better chance of seeing and counting the hiding lizard would occur.

We found that during any given "run", some lizards were glimpsed and not identified to species or whether or not they had been previously marked. In areas where Gambelia and Cnemidophorus are common, this problem is intensified as their sizes are somewhat similar. When startled, a leopard lizard will usually move away from the source of disturbance. With the addition of a second person, walking an adjacent line, the chances of identifying the lizard are increased. The final result is a more accurate and efficient assessment of lizard density.

Field studies should be designed on a site having a high number of lizards, such as site 4 or 10 , to determine whether 2,3 , or 4 cbservers working the cruise method provide the most usable data.

Tollestrup (1976) developed her technique on habitat considerably more homogeneous than the areas surveyed in this study. In or near the western foothills of Kern County, Gambelia were often concentrated in 
arcas that are discontinuously distriblited in part because the general region has been extensively nodified by man's activities. For example, at site 1 the vegetation consisting of scattered Atrinlex surrounded by dense growths of annual grasses. The grassland was almost devoid of Gambelia. However, a sandy wash and an asphalted wash traversed this plot and in these "corridors" of favorable habitat were found several blunt-nosed leopard lizards. In habitat such as this, different relative density estimates are likely to result depending upon the layout of transect lines. A transect whose lines only briefly intersect these washes will probably yield a lower relative density index than a transect whose lines traverse the washes in a number of places and for greater distances. Stratification of the sampling effort must be done in these areas where non-homogeneous habitat exists to avoid erroneous estimates of relative densities.

\section{MANAGEMENT IMPLICATIONS}

The fieldwork on blunt-nosed leopard lizards in the Taft area of California has provided us with some understanding of this species' biology. However, a lack of know]edge about its microhabitat requirements, food habits, reproductive biology, and interactions with Cnemidophorus tigris limits the development of a coherent strategy for this animal.

The washes in the Taft area appear either to be preferred habitat or refuces from the extensive alteration of habitat that has occurred around their perimeters. These areas clearly need to be protected from human disturbance. Specific management practices and controls 
for wash management include:

(1) establishment of buffer strips around the wash, 10-15 m wide, that protect it and allows its native vegetation to remain intact;

(2) restriction of vehicle use around wash edges, with vehicle crossing points $1 \mathrm{~km}$ or more apart, and the total exclusion of driving in the wash proper; and

(3) prevention of the wash being used as a disposal site for solid wastes, garbage, and oil.

An intensive study of existing washes near Taft is suggested so that the biological structure of such undisturbed habitat can be documented. This information can then be used to guide management activities so as to protect the biological structure of such communities. It is only in these washes that relic populations of blunt-nosed leopard lizards will exist after extensive development of a site for oil and gas production occurs. After the disturbence of development ceases or is reduced, then lizards from these protected areas will perhaps recolonize the disturbed areas.

If the level of development for oil and gas production is equivalent to that currently existing on sites 3 and 5 , bluni-nosed leopard lizards will probably not survive on such areas. The impact of development is many-fold. The destruction of the native vegetation on a site results in the loss of food sources, insects, and protective cover for the lizards. Excessive disturbance may disrupt lizard breeding biology and the decrease in small mamrel populations on the heavily developed sites reduces the availability of burrows for the 
lizards. Maintenance of as much native vegetation as possible with between $25-50 \%$ of the site in bare ground is necessary to promote the well-being of blunt-nosed leopard lizards. Artificial burrows could be developed for the lizards as has been done in the Pixley area of California. Lizards could be captured on the site being intensively developed and relocated in protected wash areas. However, this assumes that such habitat exists and is not already fully-stocked with blunt-nosed leopard lizards. Control of vehicle traffic on roads within the area during the months when lizards are active in the area would help prevent excessive mortality due to lizards being run over by vehicles.

Potential conflicts between Gambelia and Cnemidophorus tigris need tc be studied and appropriate management activities taken. Cnemidophorus populations may need to be reduced temporarily in areas where Gambelia will be reintroduced so as to reduce competition between -these -two species,

¿Rehabilitation of inactive oil and gas areas needs to be also considered and long-range management plans for such sites constructed. Management options for these areas include:

(1) restricting travel on existing roads and prohibiting off-road vehicle usage on such sites. Off-road vehicle activity is probably detrimental to blunt-nosed leopard lizard populations as it is to other plant and animal groups within the affected area.

(2) maintain 25-50\% of the area in openings and protect the : mative shrubs of the area from destruction. light grazing by domestic . stock on such sites thay be beneficial to blunt-nosed leopard lizards 
but overgrazing of these areas must be avoided. Light grazing also helps reduce fire danger by removing potential fuel for wildfires.

(3) selective control of Cnemidophorus tigris on such sites, at least initially, may be necessary to reduce potential competition between these two species.

Current biological knowledge provides an indication of the needs of the blunt-nosed leopard lizard in habitats in the Taft area. The use of this information to develop management plans will insure that this species will continue to survive in this area of California. Cooperation of oil and gas producers and agencies responsible for the protection and enhancement of blunt-nosed leopard lizard habitat is essential if these management plans are to be effective. 


\section{LITERATURE CITED}

Ashby, W.C. 1972. Distance measurements in vegetation study. Ecology, 53:980-981.

Bouyoucos, G.J. 1936. Directions for making hydrometer analysis of solids by the hydrometer method. Soil Sci., 42:231-255.

Brown, W. and A. Alcala. 1961. Population of amphibians and reptiles in the submontane and montane forests of Cernos de Negros, Phillipine Islands. Ecology, 42:628-636.

Bury, R.B. 1971. Status report on California's threatened amphibians and reptiles. Inland Fisheries Admin. Rept. No. 72-2, California Dept. of Fish and Game, Sacramento. $31 \mathrm{pp}$.

Canfield, R. 1941. Application of the line intercept method of sampling range vegetation. J. For., 39:388-394.

Curtis, J.T. and R.P. McIntosh. 1951. An upland forest continuum in the prairie forest border region of Wisconsin. Ecology, $32: 476-496$.

Donahue, R.L., R.W. Miller, and J.C. Shickluna. 1974. Soils--an introduction to soils and plant growth. 4th ed. Prentice-Hall, Inc., Englewood Cliffs, New Jersey. 626 pp.

Fisk, L. 1972. Protected amphibians and reptiles. Inland Fisheries Informational Leaflet No. 28, California Dept. of Fish and Game, Sacramento. $29 \mathrm{pp}$.

Montanucci, R.R. 1965. Observations on the San Joaquin leopard lizard, Crotaphytus wislizenij silus Stejneger. Herpetologia, $21: 270-283$.

- 1967. Further studies on leopard lizards, Crotaphytus wislizenii. Herpetologia, 23:119-126.

- 1.968. Notes on the distribution and ecology of some lizards in the San Joaquin Valley, California. Herpetologia, $24: 316-320$.

- 1970. Analysis of hybridization between Crotaphytus Wislizenii and Crotaphytus silus (Sauria: Iguanidae) in California. Copeia, 1970:104-123.

- 1978a. Dorsal pattern polymorphism and adaptation in Gambelia wislizenii (Reptilia, Lacertilia, Iguanidae). J. Herp. 12:73-81.

- 1978b. Discriminant analysis of hybridization between leopard lizards, Gambelia (Reptilia, Lacertilia, Iguanidae). J. Herp., 12:299- 307 . 
Mueller-Dombois, D. and H. Ellenberg. 1974. Aims and methods of vegetation ecology. John Wiley and Sons, Inc., New York. 54 pp.

Petersen, C.G.J. 1896. The yearly immigration of young plaice into Limfjord from the German Sea. Rept. Denish Biol. Sta. for 1895 , $6: 1-77$.

Phillips, E.A. 1959. Methods of vegetation study. Henry Holt and Co., Inc., New York. $107 \mathrm{pp}$.

Snow, C. 1972. Blunt-nosed leopard lizard Crotaphytus silus. Habitat Management Series for Endangered Species. Rept. No. 3, Bureau of Land Management, Denver. $13 \mathrm{pp}$.

Tollestrup, K. 1976. A standardized method of obtaining an index of densities of blunt-nosed Ieopard lizards, Crotaphytus silus. Contract 14-16-0001-579RF, U.S. Dept. of the Interior, Fish and Wildlife Service. Unpubl. Rept. $29 \mathrm{pp}$.

Zar, J.H. 1974. Biostatistical analysis. Prentice-Hall, Inc., Englewood Cliffs, New Jersey. 620 pp: 
1. General description of the 14 study sites utilized to determine the impact of oil and gas development on blunt-nosed leopard lizards in the southern San Joaquin Valley, California.

\begin{tabular}{|c|c|c|c|c|c|}
\hline $\begin{array}{c}\text { Study site } \\
\text { number }\end{array}$ & $\begin{array}{c}\text { Level of } \\
\text { development }\end{array}$ & $\begin{array}{l}\text { General } \\
\text { location }\end{array}$ & $\begin{array}{c}\text { Legal } \\
\text { description }\end{array}$ & $\begin{array}{l}\text { Elevation } \\
\text { in meters }\end{array}$ & $\begin{array}{c}\text { Vegetation } \\
\text { type }\end{array}$ \\
\hline 1 & $V 1$ & $\begin{array}{l}4 \mathrm{~km} \text { north of } \\
\text { McKittrick, } \\
\text { (Kern County) }\end{array}$ & $\begin{array}{l}\text { Sec. 4, R22E, } \\
\text { p3os, West Elk } \\
\text { Hills, Calif. }\end{array}$ & 214 & $\frac{\text { Atriplex- }}{\text { grassland }}$ \\
\hline 2 & 2 & $\begin{array}{l}1.6 \mathrm{~km} \text { east of } \\
\text { Fellows, (Kern } \\
\text { County) }\end{array}$ & $\begin{array}{l}\text { Sec. 32, R28F, } \\
\text { T31S, Fellows, } \\
\text { Calif. }\end{array}$ & 351 & $\frac{\text { Atriplex- }}{\text { grassland }}$ \\
\hline 3 & 5 & $\begin{array}{l}3.2 \mathrm{~km} \text { south of } \\
\text { Derby Acres, } \\
\text { (Kern County) }\end{array}$ & $\begin{array}{l}\text { N1/2 of Sec. } 22 \\
\text { R22E, T31S, } \\
\text { Fellows, Calif. }\end{array}$ & 458 & $\frac{\text { Atriplex- }}{\text { grassland }}$ \\
\hline 4 & 2 & $\begin{array}{l}8.8 \mathrm{~km} \text { north of } \\
\text { Taft, (Kern } \\
\text { County) }\end{array}$ & $\begin{array}{l}\text { Sec. } 24, \text { R23E, } \\
\text { T31S, Taft, } \\
\text { Calif. }\end{array}$ & 214 & $\frac{\text { Atriplex- }}{\text { grassland }}$ \\
\hline 5 & 4 & $\begin{array}{l}4.8 \mathrm{~km} \text { northwest } \\
\text { of Fellows, } \\
\text { (Kern County) }\end{array}$ & $\begin{array}{l}\text { SE/4 of Sec. } 23, \\
\text { R22स, T31S, } \\
\text { Fellows, Calif. }\end{array}$ & 412 & $\frac{\text { Atriplex- }}{\text { grassland }}$ \\
\hline 6 & $\sqrt{3}$ & $\begin{array}{l}4 \mathrm{~km} \text { southeast of } \\
\text { McKittrick, } \\
\text { (Kern County) }\end{array}$ & $\begin{array}{l}\text { Nwt' of Sec. 26, } \\
\text { R22E, } 130 \mathrm{~s} \text {, West } \\
\text { Elk tlills, Calif: }\end{array}$ & 290 & $\frac{\text { Atriplex- }}{\text { grassland }}$ \\
\hline
\end{tabular}


Table 1. (Cont.)

\begin{tabular}{|c|c|c|c|c|c|}
\hline $\begin{array}{l}\text { Study site } \\
\text { number }\end{array}$ & $\begin{array}{c}\text { Level of } \\
\text { development }\end{array}$ & $\begin{array}{l}\text { General } \\
\text { location }\end{array}$ & $\begin{array}{c}\text { Legal } \\
\text { description }\end{array}$ & $\begin{array}{l}\text { Elevation } \\
\text { in meters }\end{array}$ & $\begin{array}{c}\text { Vegetation } \\
\text { type }\end{array}$ \\
\hline 7 & 1 & $\begin{array}{l}2.4 \mathrm{~km} \text { east of } \\
\text { McKittrick, } \\
\text { (Kern County) }\end{array}$ & $\begin{array}{l}\text { Sec. 22, R22E, } \\
\text { T3OS, West Elk } \\
\text { Hills, Calif. }\end{array}$ & 282 & $\frac{\text { Atriplex- }}{\text { Grassland }}$ \\
\hline 8 & 1 & $\begin{array}{l}20.9 \mathrm{~km} \text { northwest } \\
\text { of McKittrick, } \\
\text { (Kern County) }\end{array}$ & $\begin{array}{l}\text { Sec. 1, R2OE, } \\
\text { T29s, Carneros } \\
\text { Rocks, Calif. }\end{array}$ & 275 & $\frac{\text { Atriplex- }}{\text { grassland }}$ \\
\hline 9 & 2 & $\begin{array}{l}7.2 \mathrm{~km} \text { northwest } \\
\text { of Taft, (Kern } \\
\text { County) }\end{array}$ & $\begin{array}{l}\text { N/2 of Sec. } 4, \\
\text { R23E, T32S, } \\
\text { Fellows, Calif. }\end{array}$ & 343 & $\frac{\text { Atriplex- }}{\text { grassland }}$ \\
\hline 10 & 1 & $\begin{array}{l}18.5 \mathrm{~km} \text { west of } \\
\text { Tatt, (San Luis } \\
\text { Obispo County) }\end{array}$ & $\begin{array}{l}W / 2 \text { of Sec. } 18, \\
\text { R22E, T32S, } \\
\text { Panorama Hills, }\end{array}$ & 702 & $\frac{\text { Atriplex- }}{\text { grassland }}$ \\
\hline 11 & 3 & $\begin{array}{l}3.7 \mathrm{~km} \text { northwest } \\
\text { of Fellows, (Kern } \\
\text { County) }\end{array}$ & $\begin{array}{l}\mathrm{SW} / 4 \text { of } \mathrm{Sec} .25, \\
\mathrm{R} 22 \mathrm{E}, \mathrm{T} 31 \mathrm{~S}, \\
\text { Fellows, Calif. }\end{array}$ & 397 & $\frac{\text { Atriplex- }}{\text { grassland }}$ \\
\hline 12 & 2 & $\begin{array}{l}4 \mathrm{~km} \text { northeast of } \\
\text { Maricopa, (Kerm } \\
\text { County) }\end{array}$ & $\begin{array}{l}\text { Sec. } 32, \mathrm{R} 24 \mathrm{E}, \\
\text { T12N, Pentland } \\
\text { Calif. }\end{array}$ & 168 & $\frac{\text { Atriplex- }}{\text { grassland }}$ \\
\hline
\end{tabular}


Table 1. (Cont.)

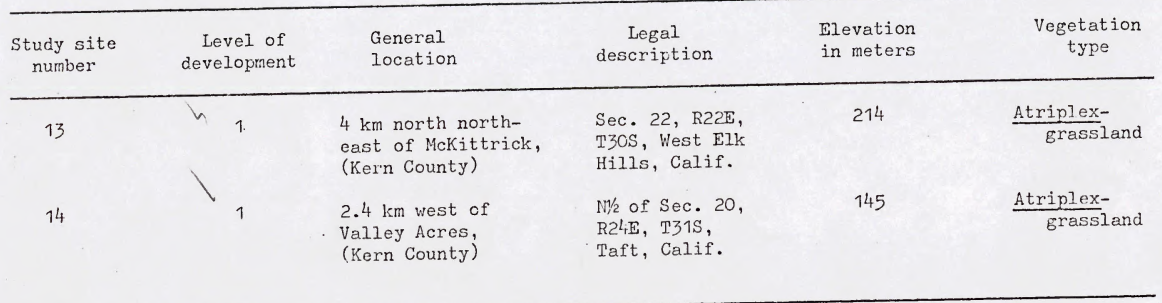


Table 2. Vascular plants present on the 14 study sites used to determine the impact of oil and gas development on the blunt-nosed leopard lizard in the southern San Joaquin Valley, California.

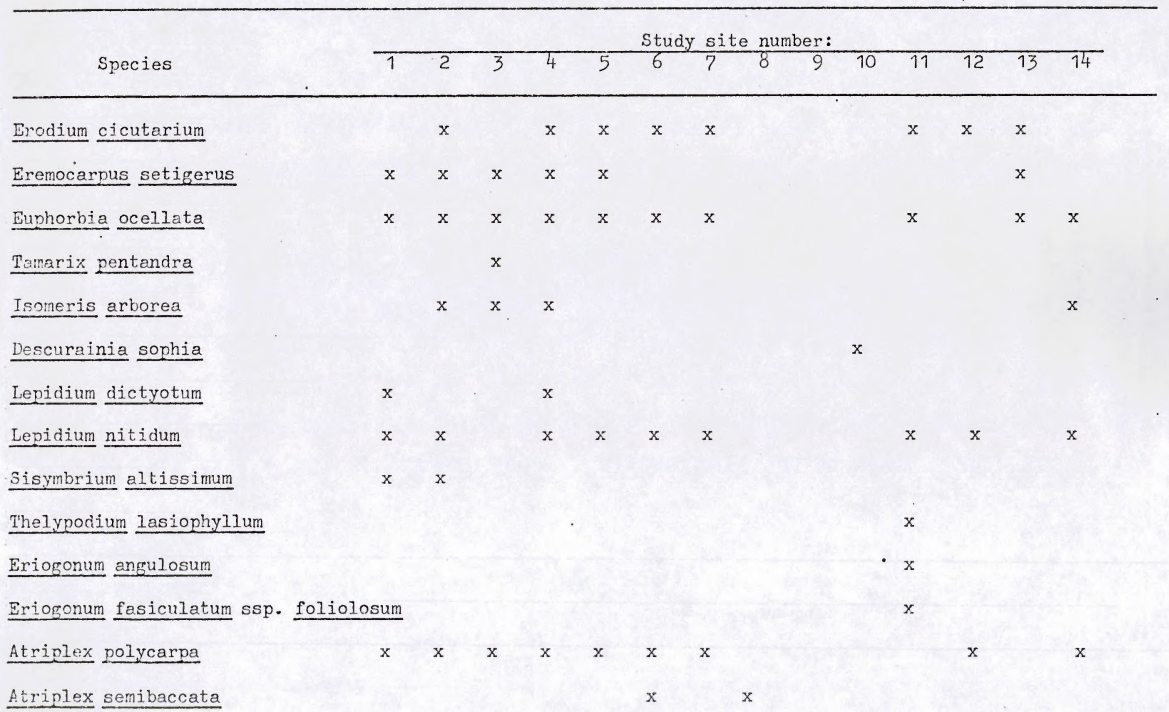


Table 2: (Cont.)

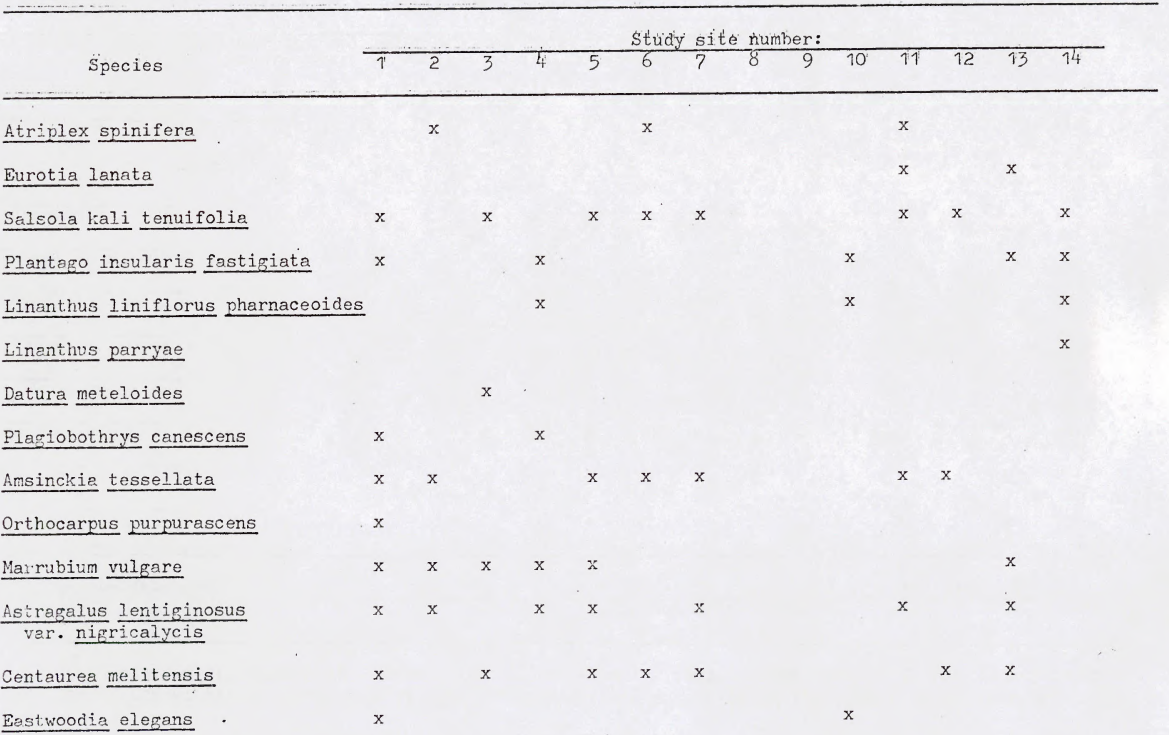


Table 2. (Cont.)

Study site number:

Species

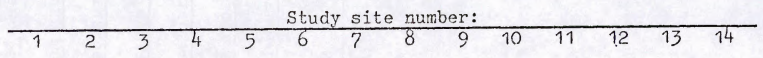

Haplopappus acradenius bracteosus $\mathrm{x}$

Helianthus annuus

IIymenoclea salsola

Lactuca serriola

Stephanomeria pauciflora

Bromus rubens

Eromus diandris

Bromús molitis

Festuca inyuros

Avena barbata

Schismus arabicus

Horcieum levorinum

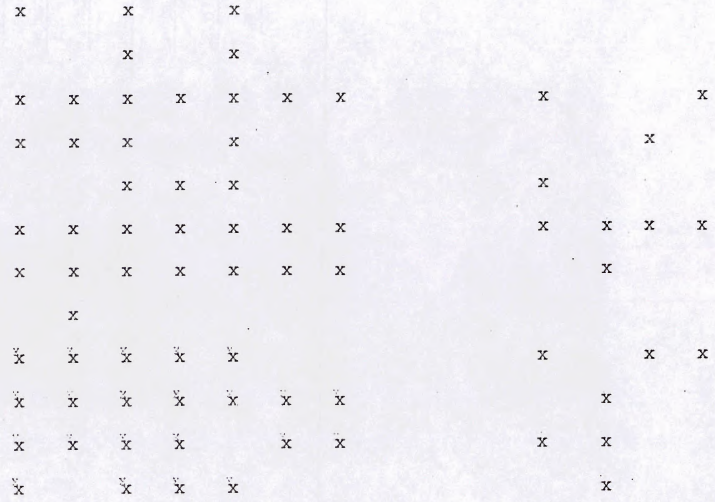


Table 3. Vascular plants considered to be reliable indicators of disturbed habitat near Taft, California.

\begin{tabular}{|c|c|c|c|c|c|}
\hline \multirow[b]{2}{*}{ Species } & \multicolumn{5}{|c|}{ Study site number: } \\
\hline & 1 & 2 & 3 & 4 & 5 \\
\hline Sisymbrium altissinum & $\mathrm{x}$ & $\mathrm{x}$ & & & \\
\hline Atriolex semibaccata & & & & & $x$ \\
\hline$\frac{\text { Salsola }}{\text { var. } \frac{\text { kali }}{\text { enuifolia }}}$ & $\mathrm{x}$ & & $\mathrm{x}$ & & $\mathrm{x}$ \\
\hline Datura meteloides & & & $\mathrm{x}$ & & \\
\hline Marrubium vulgare & $\mathrm{x}$ & $\mathrm{x}$ & $\mathrm{x}$ & $\mathrm{x}$ & $\mathrm{x}$ \\
\hline Centaurea melitensis & $\mathrm{x}$ & & $\mathrm{x}$ & & $\mathrm{x}$ \\
\hline Helianthus annuus & & & $\mathrm{x}$ & & $\mathrm{x}$ \\
\hline Lactuca serriola & & & $\mathrm{x}$ & & $x$ \\
\hline Bromus diandris & $\mathrm{x}$ & $\mathrm{x}$ & $\mathrm{x}$ & $\mathrm{x}$ & $\mathrm{x}$ \\
\hline
\end{tabular}


Table 4: Composition of vascular vegetation on intensive study site number 1, near Taft, California, May-July 1979.

\begin{tabular}{|c|c|c|c|c|c|c|}
\hline \multirow[b]{2}{*}{ Species } & \multicolumn{4}{|c|}{ Percent } & \multirow[b]{2}{*}{$\begin{array}{l}\text { Importance } \\
\text { value }\end{array}$} & \\
\hline & Cover & $\begin{array}{l}\text { Relative } \\
\text { dominance }\end{array}$ & Frequency & $\begin{array}{l}\text { Relative } \\
\text { frequency }\end{array}$ & & \\
\hline Bromus rubens & 67.77 & 55.74 & 100 & 10.87 & 66.61 & \\
\hline Atriblex polycarpa & 18.01 & 14.81 & 100 & 10.87 & 25.68 & \\
\hline Schismus arabicus & 11.60 & 9.54 & 100 & 10.87 & 20.41 & \\
\hline Erodium cicutarium & 5.70 & 4.02 & 90 & 9.78 & 13.80 & \\
\hline Salsola kali & 2.31 & 1.90 & 90 & 9.78 & 11.68 & \\
\hline Eromus diandrus & .1 .56 & 1.47 & 90 & 9.78 & 11.15 & \\
\hline Lepidium nitidum & 1.21 & 1.00 & 80 & 8.70 & 9.70 & \\
\hline Plagiobothrys canescens & 0.72 & 0.58 & 50 & 5.43 & 6.01 & \\
\hline Festuca myuros & 0.43 & 0.35 & 40 & 4.35 & 4.70 & \\
\hline Plantaso insularis & 1.24 & 1.02 & 30 & 3.26 & 4.28 & \\
\hline Eremocarpus setigerus & 0.27 & 0.22 & 10 & 1.09 & 1.31 & \\
\hline Lepidium dictyotum & 0.10 & 0.08 & 10 & 1.09 & 1.17 & \\
\hline Hordeum Ieporinum & 0.08 & 0.07 & 10 & 1.09 & 1.16 & 5 \\
\hline
\end{tabular}


Tabie 4: (Cont.)

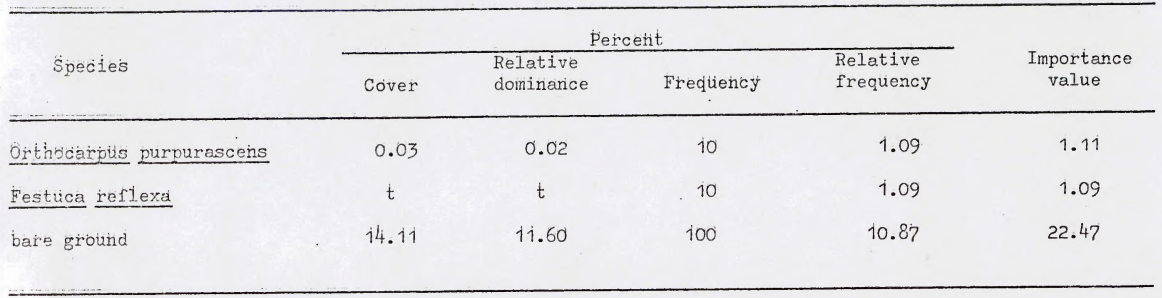


Table 5. Composition of vascular vegetation on intensive study site number 2, near Taft, California, May-July 1979.

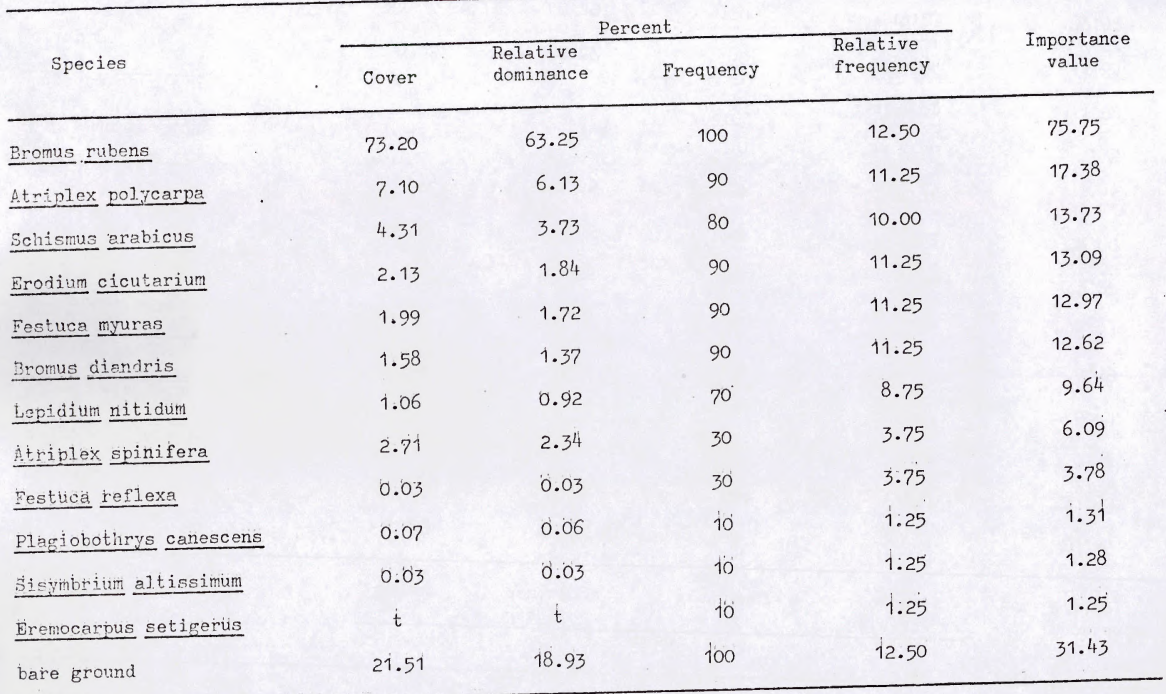


Table 6. Composition of vascular vegetation on intensive study site number 3 , near Taft; California; May-July 1979.

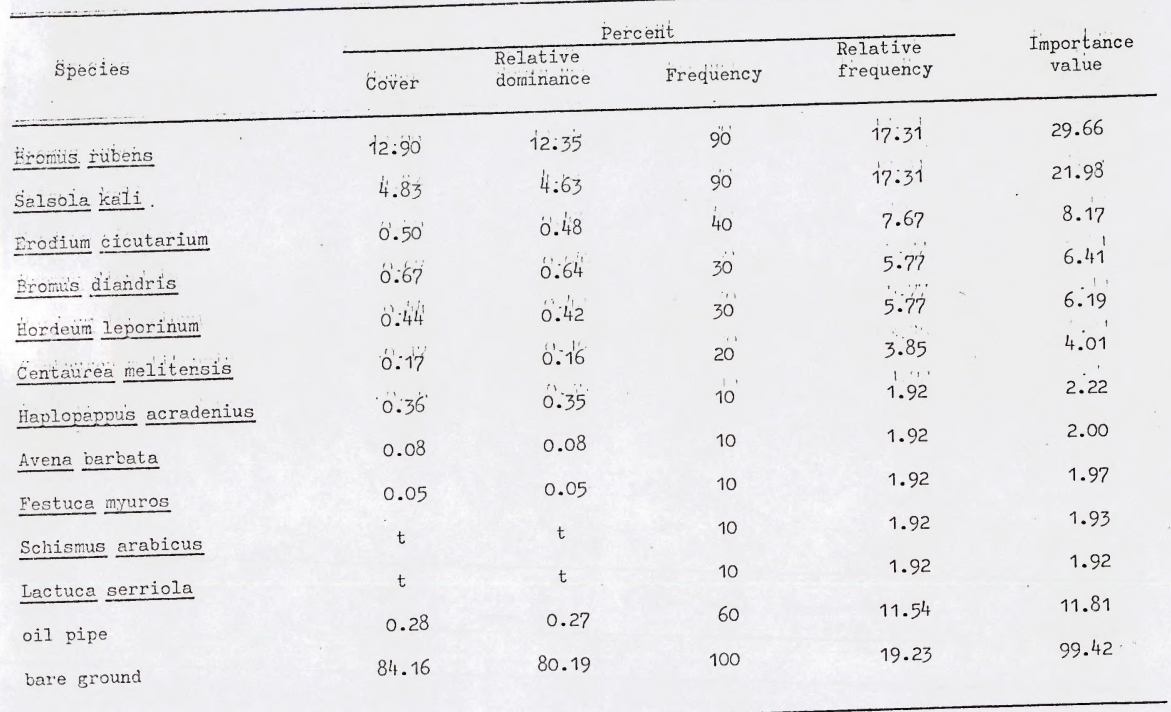


Tabie 7: Composition of vascular vegetation on intensive study site number 4 , near Taft, California, May-July 1979:

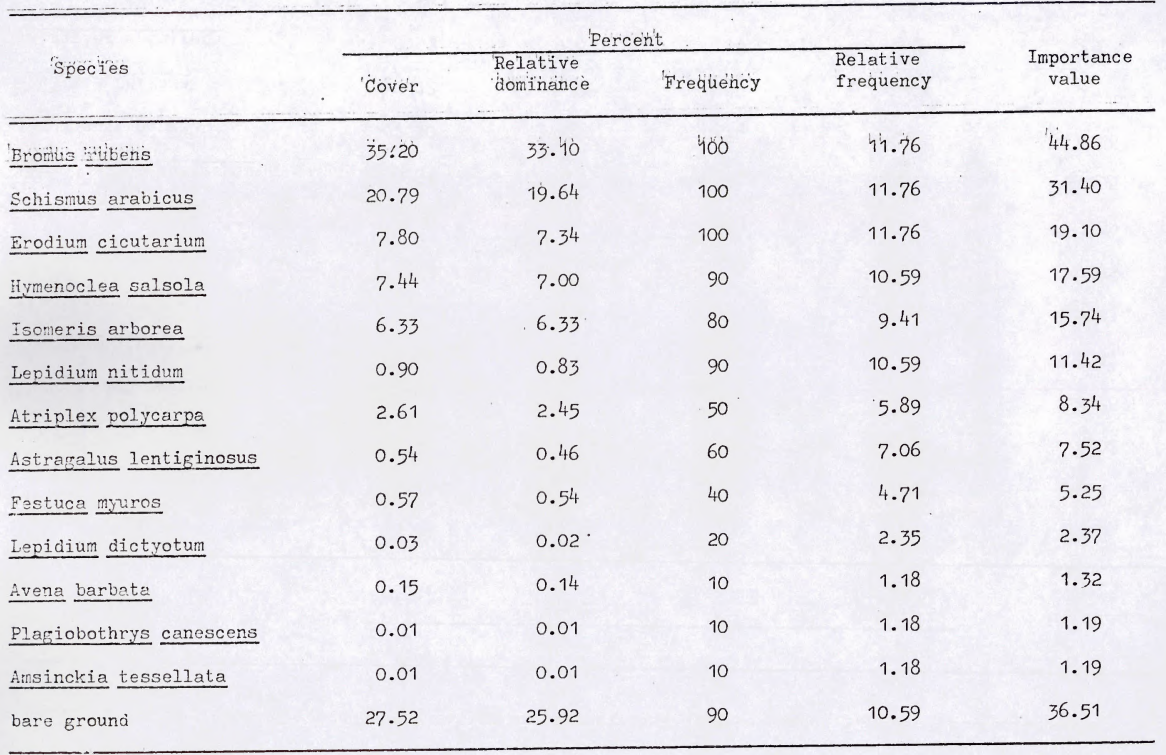


Table 8. Composition of vascular vegetation on intensive study site number 5, near Taft, California, Iray-July 1979.

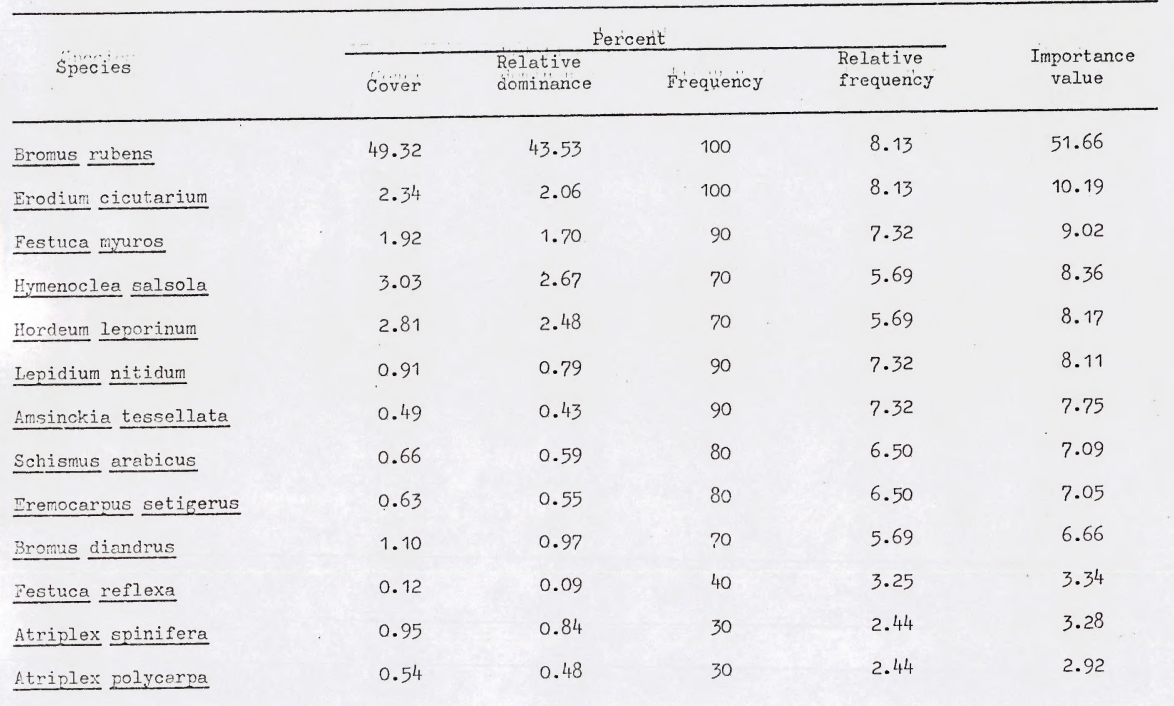


Table 8. (Cont.)

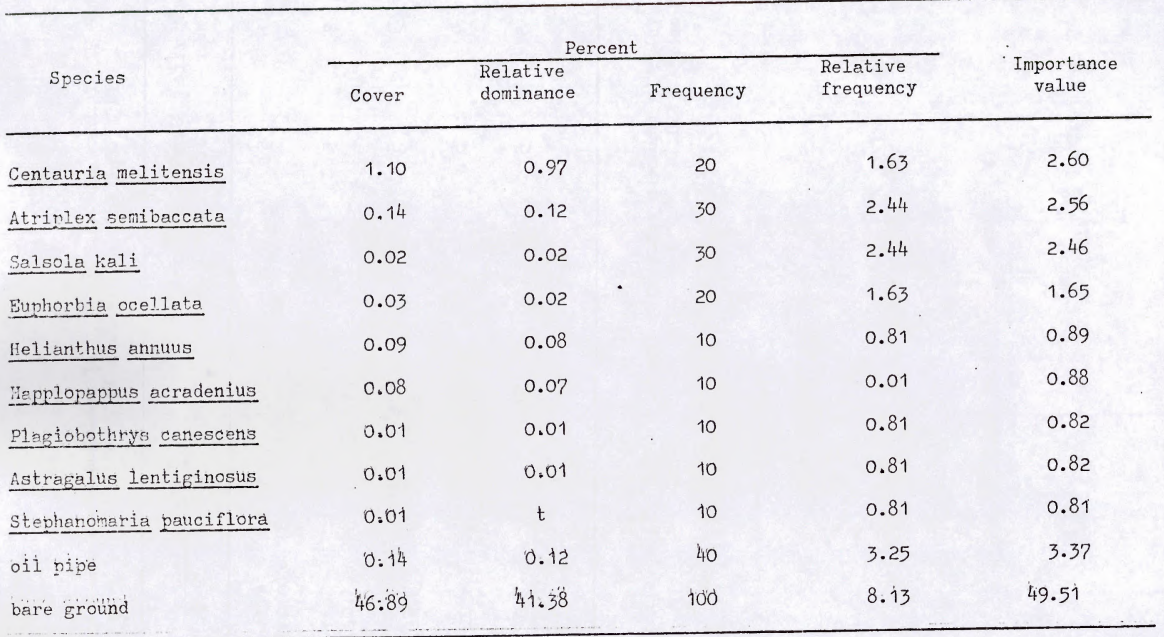


Table 9. Texture and bulk density of soils on study sites 1-5 near Taft, Cetifornia, May-July 1979.

\begin{tabular}{|c|c|c|c|c|c|c|}
\hline \multirow{2}{*}{$\begin{array}{l}\text { Study site } \\
\text { number }\end{array}$} & \multirow{2}{*}{$\begin{array}{l}\text { Sample } \\
\text { size }\end{array}$} & \multirow{2}{*}{$\begin{array}{c}\text { Level of } \\
\text { development }\end{array}$} & \multicolumn{3}{|c|}{ Percent } & \multirow{2}{*}{$\begin{array}{l}\text { Bulk } \\
\text { density }\end{array}$} \\
\hline & & & sand & silt & clay & \\
\hline 1 & 5 & 1 & $\begin{array}{l}84.5 \\
(5.67)^{1}\end{array}$ & $\begin{array}{l}11.4 \\
(4.68)\end{array}$ & $\begin{array}{c}4.1 \\
(0.99)\end{array}$ & $\begin{array}{l}1.568 \\
(.0496)\end{array}$ \\
\hline 2 & 5 & 1 & $\begin{array}{l}62.6 \\
(1.76)\end{array}$ & $\begin{array}{l}31.1 \\
(1.38)\end{array}$ & $\begin{array}{l}6.3 \\
(1.02)\end{array}$ & $\begin{array}{l}1.448 \\
(.0282)\end{array}$ \\
\hline 3 & 5 & 5 & $\begin{array}{l}68.8 \\
(2.95)\end{array}$ & $\begin{array}{l}27.3 \\
(2.74)\end{array}$ & $\begin{array}{l}3.9 \\
(0.46)\end{array}$ & $\begin{array}{l}1.586 \\
(.0344)\end{array}$ \\
\hline 4 & 5 & 2 & $\begin{array}{l}61.7 \\
(1.49)\end{array}$ & $\begin{array}{l}33.1 \\
(1.53)\end{array}$ & $\begin{array}{l}5.2 \\
(0.92)\end{array}$ & $\begin{array}{l}1.854 \\
(.0229)\end{array}$ \\
\hline 5 & 5 & 4 & $\begin{array}{l}57.7 \\
(2.28)\end{array}$ & $\begin{array}{l}32.8 \\
(1.45)\end{array}$ & $\begin{array}{l}9.5 \\
(1.37)\end{array}$ & $\begin{array}{l}1.444 \\
(.0248)\end{array}$ \\
\hline
\end{tabular}

1Value in brackets represents standard error of the estimate of the mean ( 1 SE). 
Tabie io: Vertebrates present on the 14 study sites üsed to determine the impact of oil and gas development tion Sañ Joaquin Valley, California, May-July 1979. on the blunt-nosed leopard lizard in the southern San Joadian Valley, Caifornia, May-July

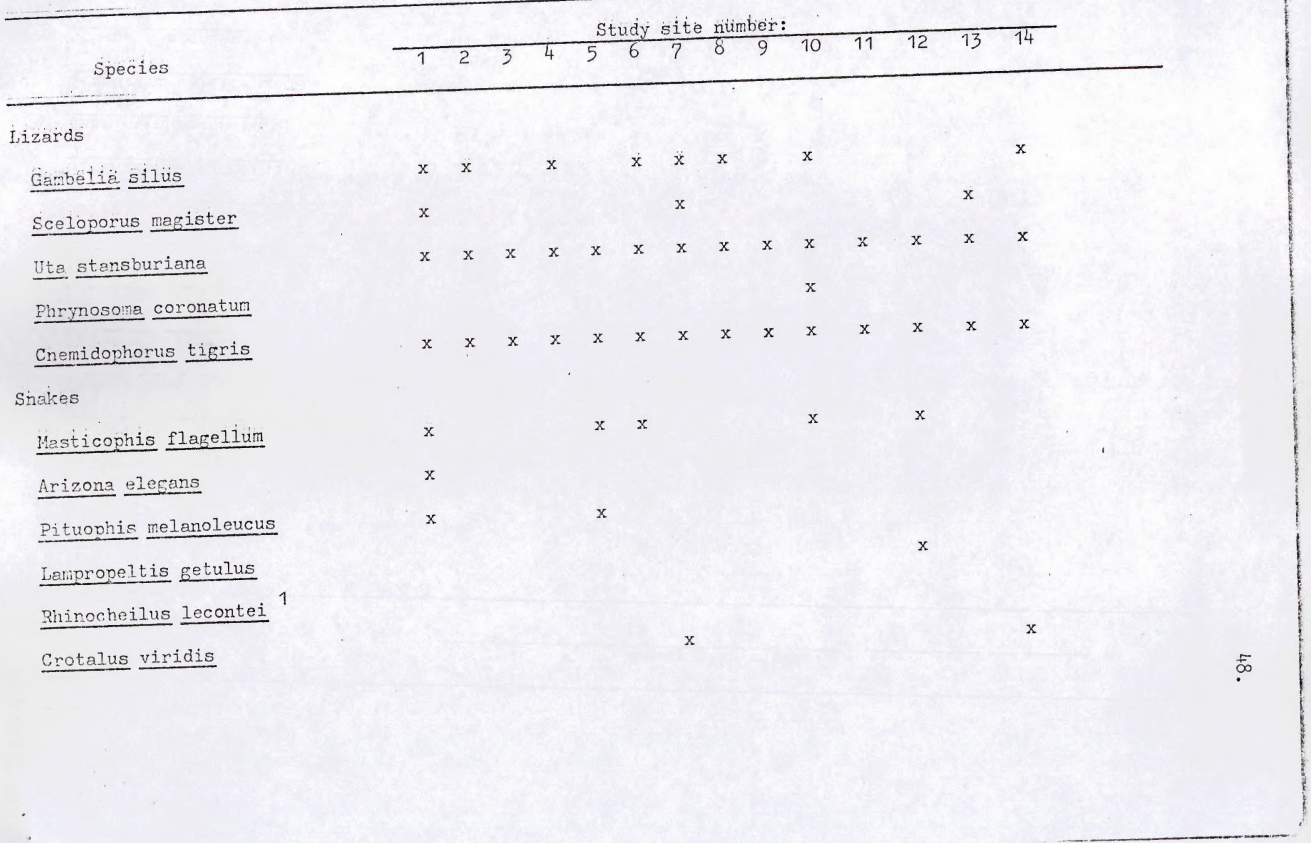


Table 10. (Cont.)

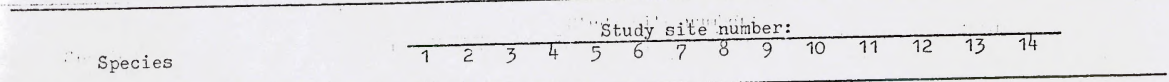

Biròs

Cathartes aura

Buteo jamaicensis

Aquila chrysaetos

Circus cyaneus

Falco sparverius

Lonhortyx cEilfornicus

Charedrius vociferus

Recurvirostra americana

Himantopus mexicanus

Zeneidura macroura

Geococcyx celifornicus

Athene cunicularia

Tyto alba

Crordeiles acutipennis

125392011

$\mathrm{x}$

$\mathrm{x}$

$x$

$\mathrm{x} \quad \mathrm{x}$

$$
\mathrm{x}
$$


Trovtr th. (

Table 10. (Cont.)

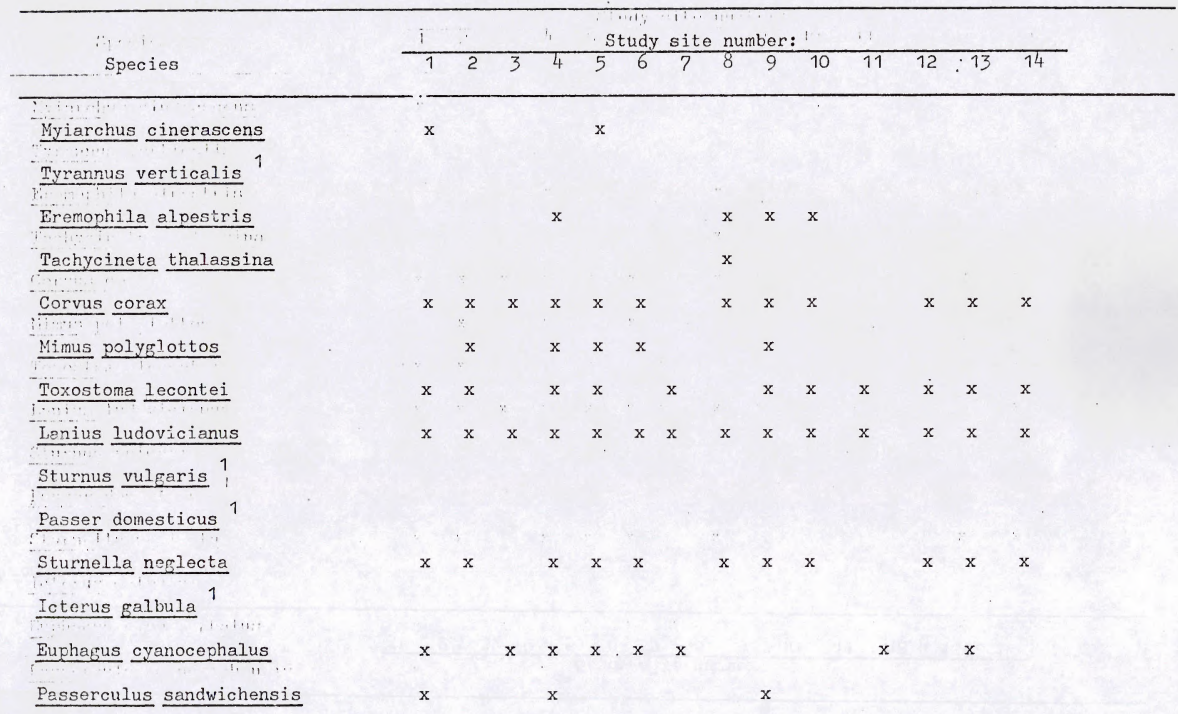


Table 10. (Cont.)

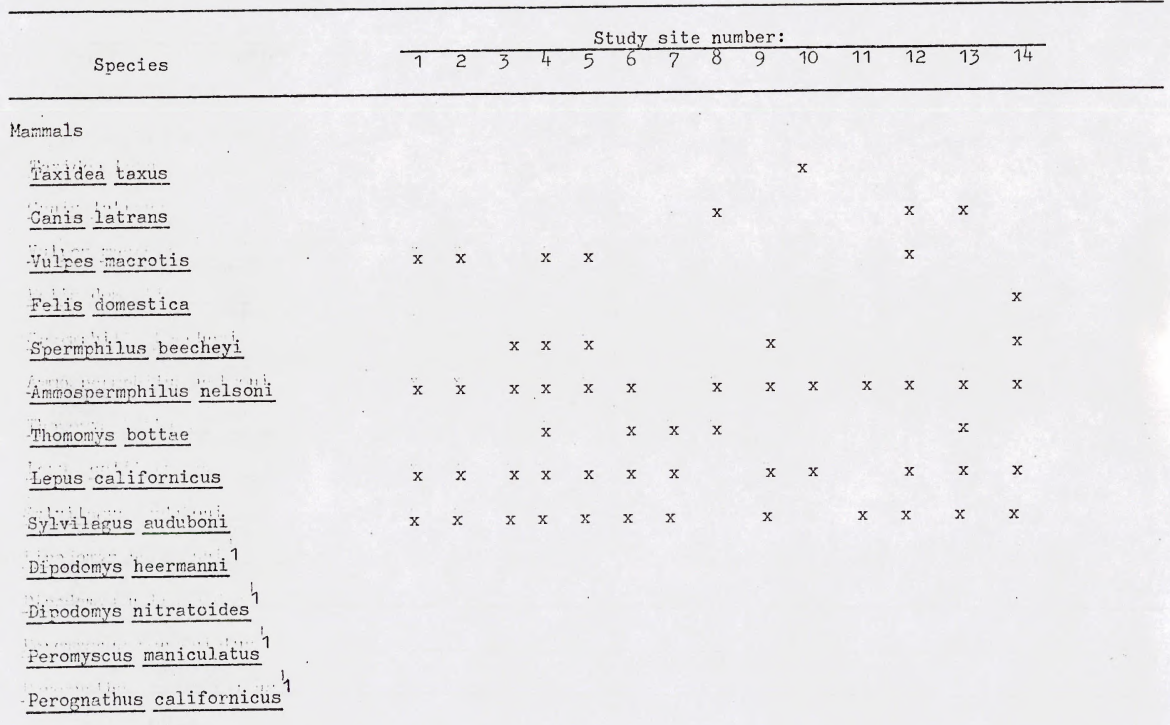


Table 10. (Cont.)

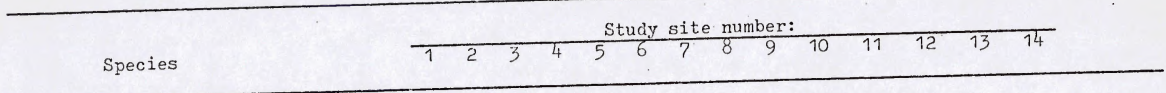

Perognathus inornatus $^{1}$

Re.ithrodontomys megalotis ${ }^{1}$

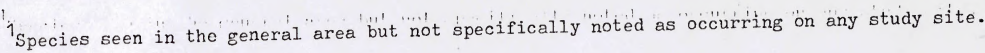


Table 11. Relative densities of 'lizards on 14 study sites near Taft, California, during June-July 1979, based on transect counts.

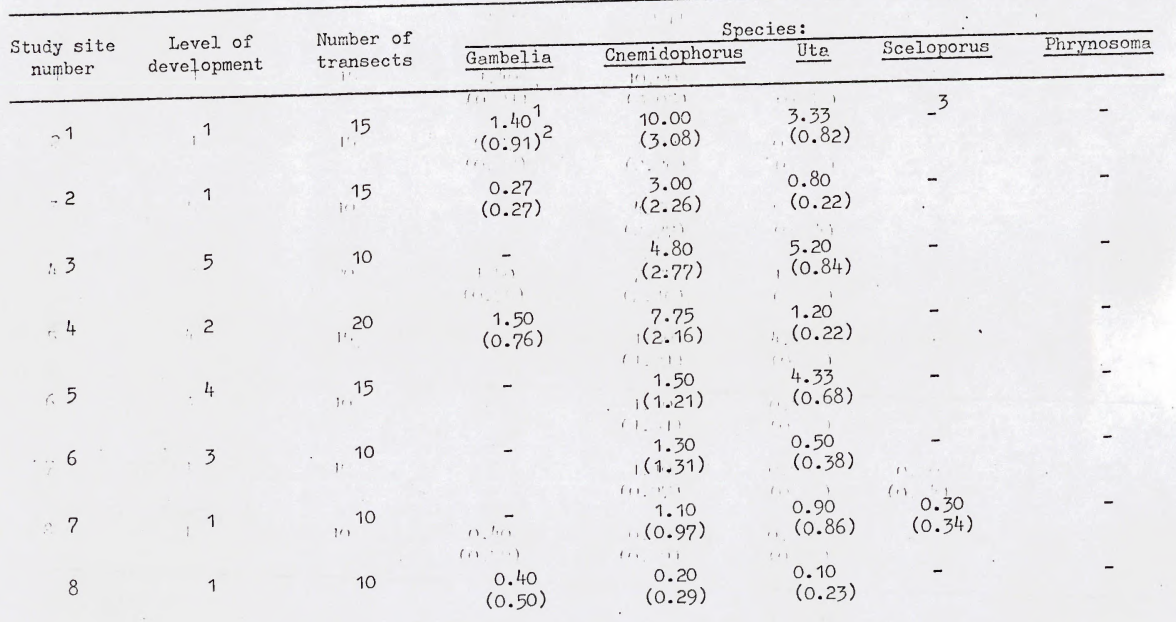


Tabie 11. (Cont.)

\begin{tabular}{|c|c|c|c|c|c|c|c|}
\hline \multirow{2}{*}{$\begin{array}{l}\text { Study site } \\
\text { number }\end{array}$} & \multirow{2}{*}{$\begin{array}{l}\text { Level of } \\
\text { development }\end{array}$} & \multirow{2}{*}{$\begin{array}{l}\text { Number of } \\
\text { transects }\end{array}$} & \multicolumn{5}{|c|}{ Species: } \\
\hline & & & Gambelia & Cnemidophorus & Uta & Scleoporus & Phrynosoma \\
\hline 9 & 3 & 10 & - & $\begin{array}{c}1.30 \\
(0.84)\end{array}$ & $\begin{array}{c}1.00 \\
(0.68)\end{array}$ & - & - \\
\hline 10 & $\begin{array}{l}1 \\
.\end{array}$ & 10 & $\begin{array}{l}3.10 \\
(1.33)\end{array}$ & $\begin{array}{l}5.70 \\
(2.37)\end{array}$ & $\begin{array}{l}3.60 \\
(1.85)\end{array}$ & - & $\begin{array}{c}0.30 \\
(0.34)\end{array}$ \\
\hline 11 & 3 & 10 & $\begin{array}{c}0.30 \\
(0.34)\end{array}$ & $\begin{array}{l}3.70 \\
(1.72)\end{array}$ & $\begin{array}{l}11.40 \\
(4.38)\end{array}$ & - & - \\
\hline 12 & 2 & 10 & - & $\begin{array}{c}8.10 \\
(4.07)\end{array}$ & $\begin{array}{l}21.80 \\
(3.32)\end{array}$ & - & - \\
\hline 13 & 1 & 10 & $\begin{array}{c}0.20 \\
(0.29)\end{array}$ & $\begin{array}{c}7.30 \\
(3.59)\end{array}$ & $\begin{array}{l}3.80 \\
(1.90)\end{array}$ & $\begin{array}{c}0.10 \\
(0.23)\end{array}$ & - \\
\hline 14 & 1 & 10 & $\begin{array}{c}0.60 \\
(0.49)\end{array}$ & $\begin{array}{c}6.00 \\
(2.44)\end{array}$ & $\begin{array}{c}0.80 \\
(0.52)\end{array}$ & - & - \\
\hline
\end{tabular}

Average number of animals seen per transect.

$Z_{\text {Valiue in }}$ parentheses represents two standard errors of the estimate.

${ }^{3}$ No lizards observed during the runining of the transects. 
Table 12. Estimates of averaze relative densities and absolute densities of blunt-nosed leopard lizards on intensive study sites 1-5 near Taft, California, during Nay-July 1979.

\begin{tabular}{|c|c|c|c|c|c|}
\hline $\begin{array}{l}\text { Study site } \\
\text { number }\end{array}$ & $\begin{array}{l}\text { Level of } \\
\text { development. }\end{array}$ & $\begin{array}{l}\text { Average } \\
\text { relative } \\
\text { density// }\end{array}$ & $\begin{array}{l}\text { total } \\
\text { marked }\end{array}$ & 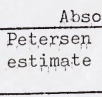 & $\begin{array}{l}\text { ute density: } \\
\text { Estimated range of lizards } \\
\text { likely present on site }\end{array}$ \\
\hline 1 & 1 & 1.40 & 7 & 8.8 & $9-10^{3}$ \\
\hline 2 & $\pi$ & 0.27 & 1 & -1 & $2-3$ \\
\hline 3 & 5 & 0.00 & 0 & - & 0 \\
\hline 4 & 2 & 1.50 & 10 & $\begin{array}{r}24.5^{2} \\
(21.4)\end{array}$ & $15-20$ \\
\hline 5 & 4 & 0.00 & 0 & - & $0-1$ \\
\hline
\end{tabular}

1 Insufficient numbers of lizards marked and/or recovered, to, use ${ }_{\text {Petersen }}$ estimate technique.

${ }^{2}$ An inflated estimate with 6 estimates, of 40 , lizards, produced a higher average than may be reasonable. Value in parentheses represents average Petersen estimate, based on 5 samples which ranged in values from 15 to 27.

3 Based on extensive:fjeldwork on study sites these values, represent what we, feel are reasonable boundaries of blunt-nosed lleopard lizizards, present, on each site. 
Table 13. Density of animal burrows on intensive study sites 1-5 near Taft, California, during May-July 1979.

\begin{tabular}{|c|c|c|c|c|c|}
\hline \multirow[t]{2}{*}{$\begin{array}{l}\text { Study site } \\
\text { number }\end{array}$} & \multirow[t]{2}{*}{$\begin{array}{l}\text { Level of } \\
\text { development }\end{array}$} & \multirow[t]{2}{*}{$\begin{array}{l}\text { Sample } \\
\text { size }\end{array}$} & \multicolumn{2}{|c|}{$\begin{array}{l}\text { Burrow density } \\
\text { per: }\end{array}$} & \multirow[t]{2}{*}{$\begin{array}{l}\text { Average burrow } \\
\text { diameter in min }\end{array}$} \\
\hline & & & acre & hectare & \\
\hline 1 & 1 & 5 & $\begin{array}{l}82 \\
(25)^{1}\end{array}$ & $\begin{array}{r}203 \\
(62)\end{array}$ & $\begin{array}{c}41 \\
(3.2)\end{array}$ \\
\hline-2 & 1 & 5 & $\begin{array}{l}31 \\
(6)\end{array}$ & $\begin{array}{r}77 \\
(14)\end{array}$ & $\begin{array}{l}48 \\
(6.5)\end{array}$ \\
\hline-3 & 5 & 5 & $\left(\begin{array}{l}6 \\
6\end{array}\right)$ & $\begin{array}{l}16 \\
(16)\end{array}$ & $\begin{array}{l}55 \\
(8.0)\end{array}$ \\
\hline-4 & 2 & 10 & $\begin{array}{l}74 \\
(12)\end{array}$ & $\begin{array}{c}182 \\
(29)\end{array}$ & $\begin{array}{c}47 \\
(7.8)\end{array}$ \\
\hline$=5$ & 4 & 5 & $\begin{array}{l}71 \\
(25)\end{array}$ & $\begin{array}{c}176 \\
(63)\end{array}$ & $\begin{array}{l}40 \\
(5.8)\end{array}$ \\
\hline
\end{tabular}

${ }^{1}$ Value in parentheses represents 2 standard errors of the estimate : of - the mean (2 SE). 
Table 14. Correlation coefficients (Spearmans rho) for relative densities of lizards and environmental conditions on 14 Study sites near Taft, California, May-July 1979.

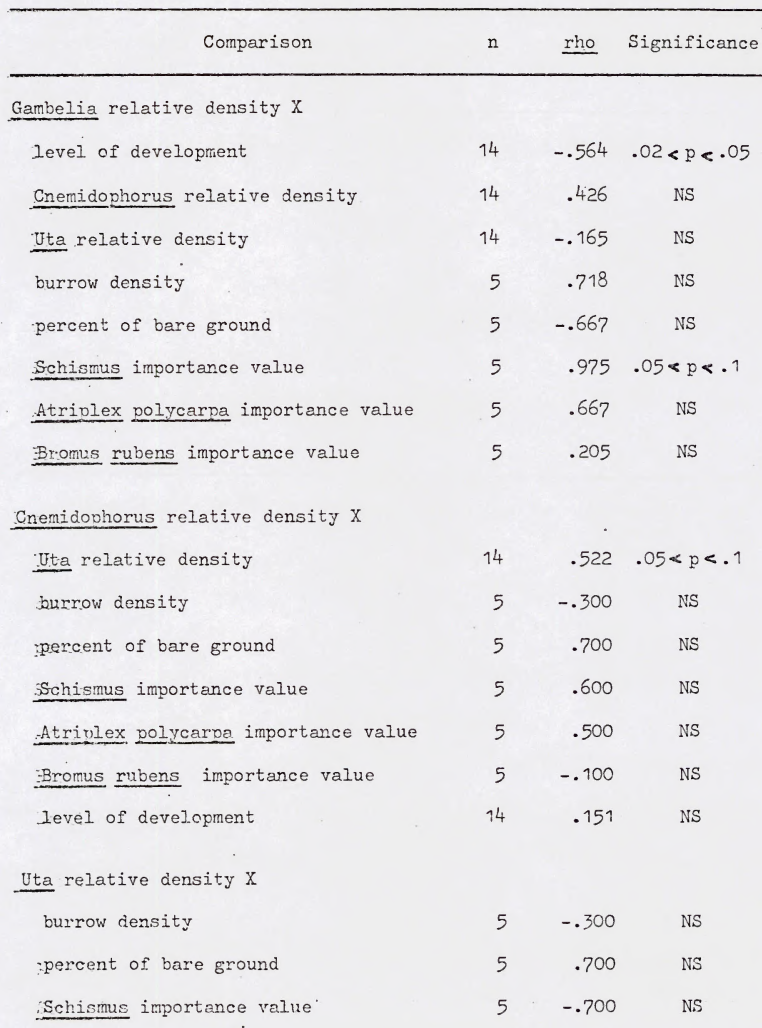


Table 14. (Cont.)

Comparison

n tho Significance ${ }^{1}$

Uta relative density $\mathrm{X}$

Bromus rubens importance value

$5 \quad-.700 \quad$ NS

level of development

$14 \quad .440 \quad$ NS

Importance value of Atriplex polycarpa $X$

burrow density

$5 \quad .700 \quad$ NS

importance value of Schismus

$5 \quad .700 \quad$ NS

importance value of Bromus rubens

$5 \quad .800 \quad$ NS

Ievel of development

$5 \quad-.975 \quad .05<p<.1$

Level of development $\mathrm{X}$

burrow density

percent of bare ground

Schismus importance value

Bromus rubens importance value

$5 \quad-.564 \quad$ NS

$5 \quad .975 \quad .05<p<. .1$

$5 \quad-.667$ NS

$5 \quad-.372$ NS

Burrow density $\mathrm{X}$ percent of bare ground

$5 \quad-.700 \quad$ NSS

Importance value of Schismus $X$ importance value of Bromus rubens

$5 \quad .500 \quad$ NS

Gambelia absolute density X level of development

$14 \quad-.576 \quad .02<p<.05$

1 NS indicates no statistical significance below the $90 \%$ (.1) level of probability. 
Appendix 1. Example of data recording form used for burrow survey. FOIPR CUATEER BURRCW. SUKVEI FORM

COUN.T:

SIIE HUNSER:

LTIS NUIBER:

DATE SAMPLED:
INVESTIGATORS:

FIDID NOTES:

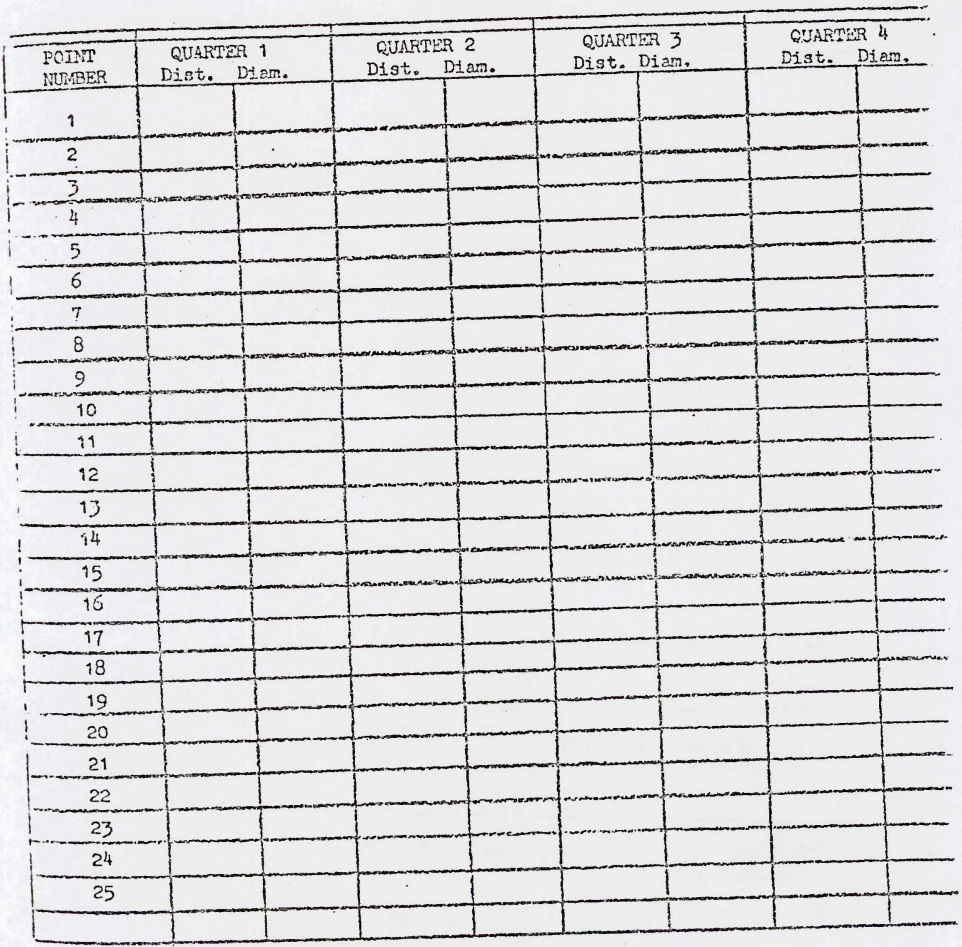


Appendix 2. Transect method of plant community description.

The line-intercept method of plant sampling is one-dimensional.

It consists of taking observations on a line or lines laid out randomly over the study area. All plants touching the line are identified to species and the length of their intercept along the transect recorded. The following calculations were made from the Iine-intercept data:

(1) Dominance or Cover (as percent of ground's surface) = total of intercept length of a species $X 100$ total transect length

(2) Relative Dominance = $\frac{\text { total intercept length of a species }}{\text { total intercept length for all species }} \times 100$

(3) Frequency $=$ number of transects in which a species occurred $x \quad 100$ total number of transects taken

(4) Relative Frequency $=$ $\frac{\text { frequency value for a species }}{\text { toval frequency values for all species }} \times 100$

(5) Importance Value $=$ relative frequency + relative dominance 


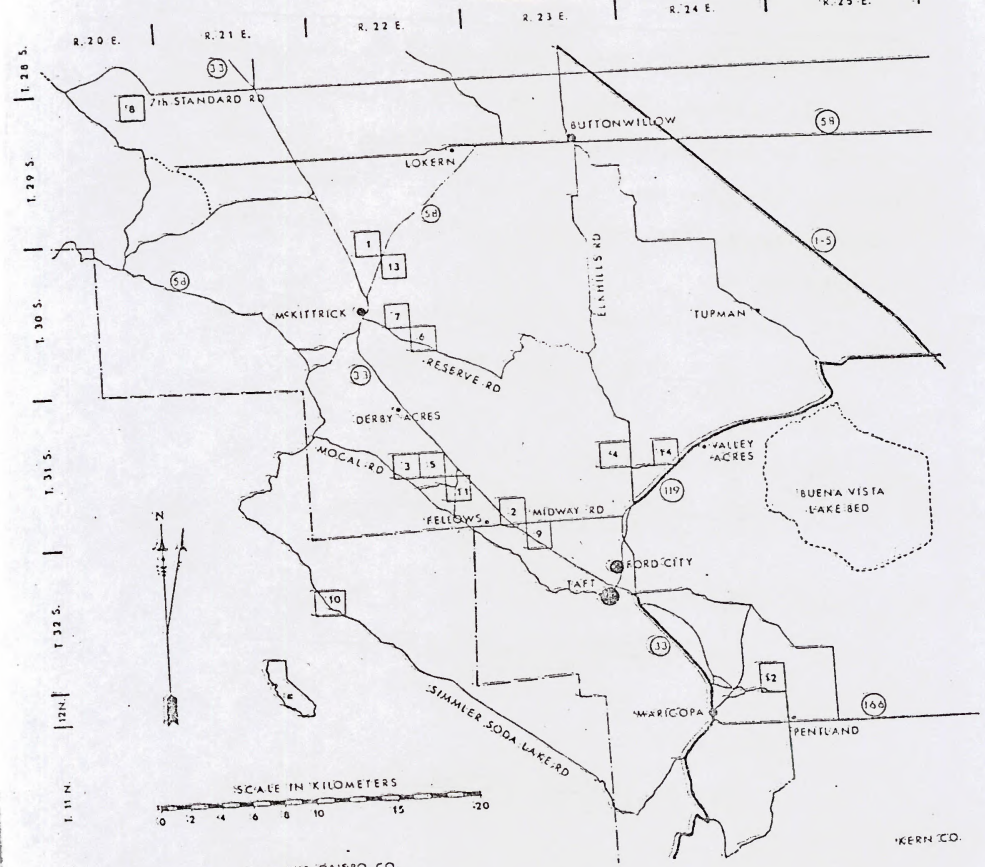

SAN.IUIS OGISPO CO

Fig. 1. Locations of the $1 / 4$ study sites in the southern San Joaquin Valley used to determine the impact of oil and gas development con blunt-nosed leopard lizards, May-July 1979. 


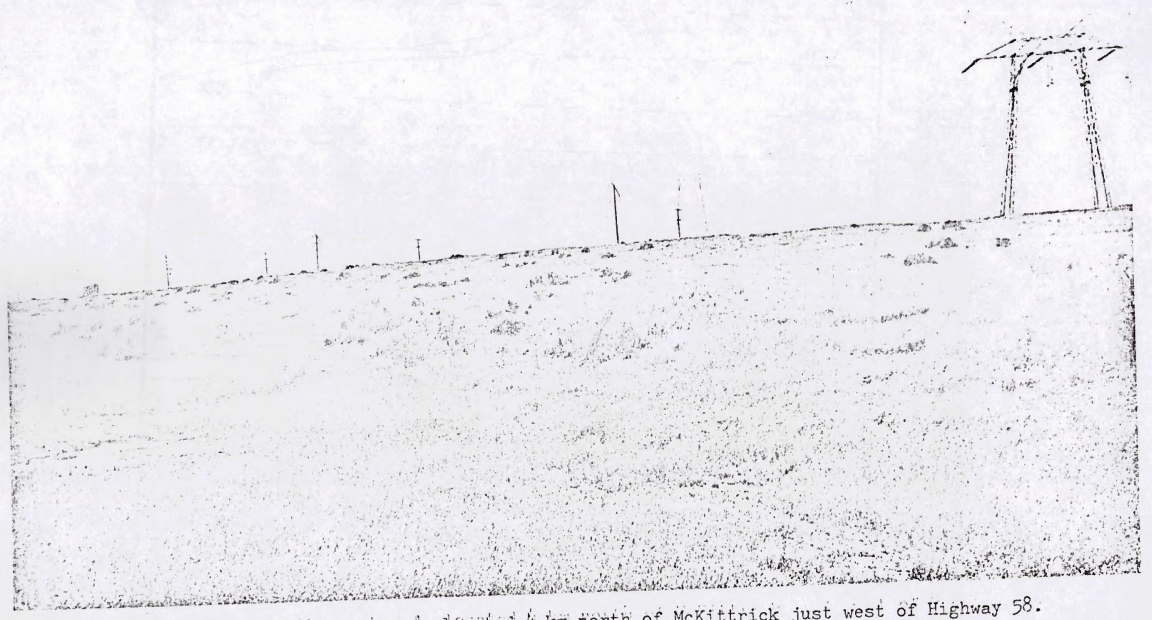

Fig: 2. Intensive study site number 1 ; located $4 \mathrm{~km}$ north of Mckittrick just west of Highway 58. Photograph by Tom Cambolil; 2 June 1979 : 


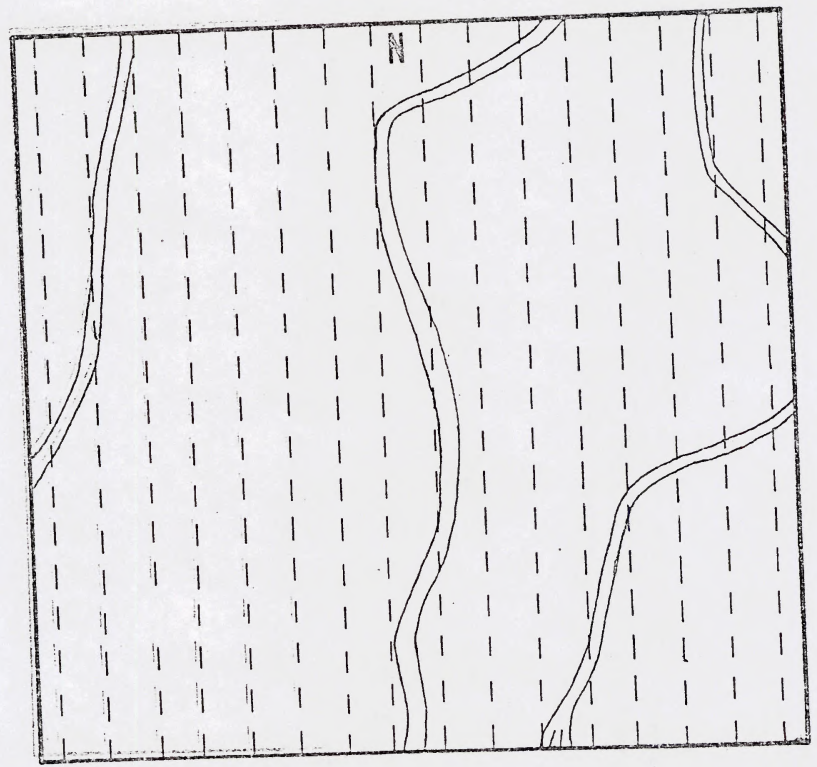

Fig. 3. Outline map of intensive study site number 1 . The terrain of this plot was fairly level and was traversed by 3 washes. - Dashed-ines indicate routes used for the relative density éstimates. 


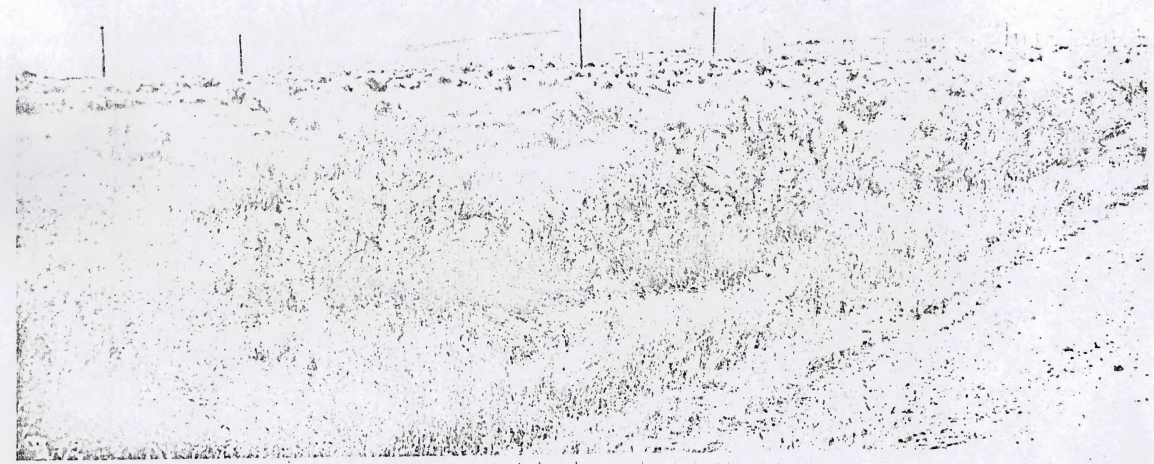

Fig. 4. Intensive study site number 2; located $1.6 \mathrm{~km}$ east of Fellows on Midway Road... Photograph by Tom Campbell 1 Junë 1979. 


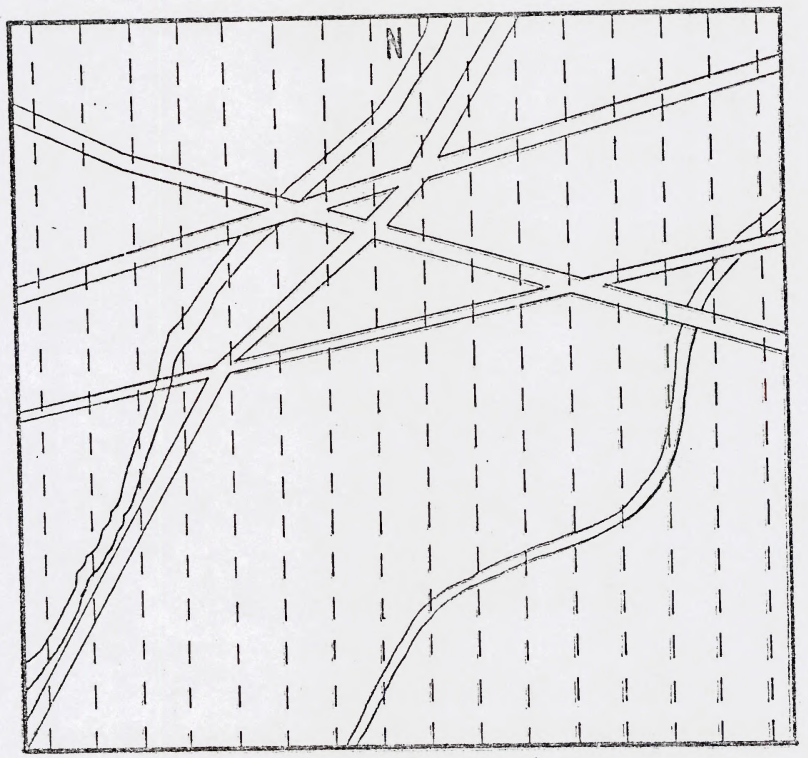

Fig- 5. Outline map of intensive study site number 2. Four roads traversed this site and 2 washes occurred within it. 


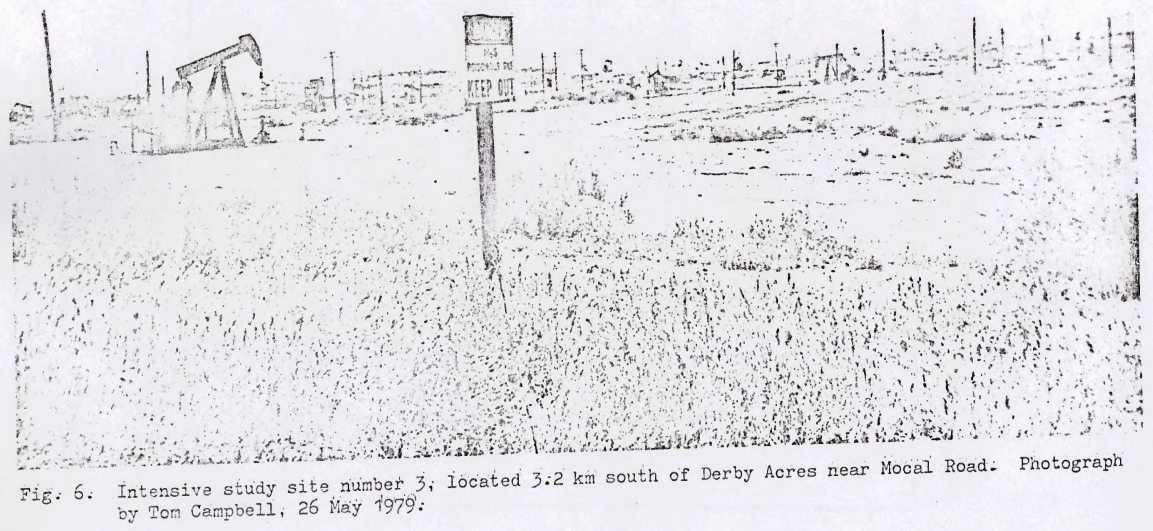




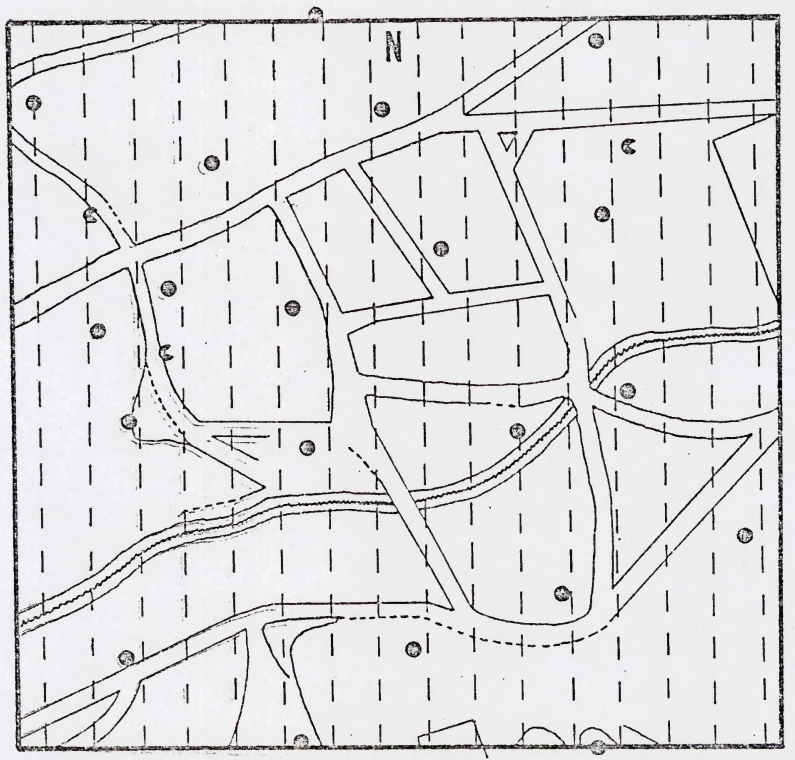

Fig. 7. Outline map of intensive study site 3.0 Oil and gas structures active on the site are represented by partial and entire, solid cjircles. 


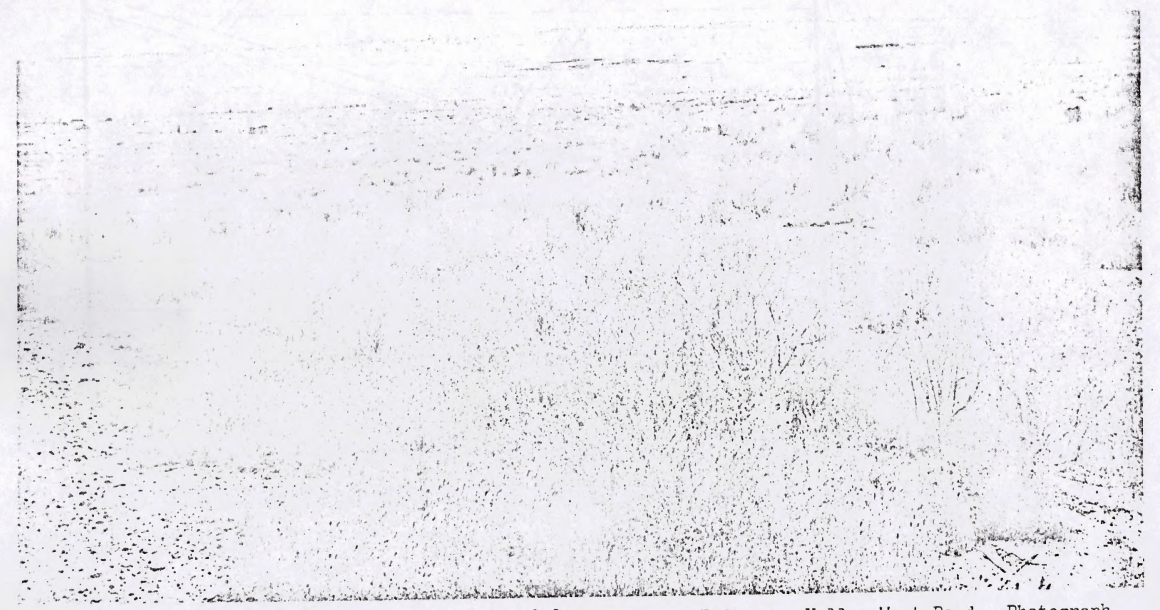

Fig. 8. Intensive study site number 4 , located $8.8 \mathrm{~km}$ north of Taft near Valley West Road. Photograph by Ton Campbell, 12 June 1979. 


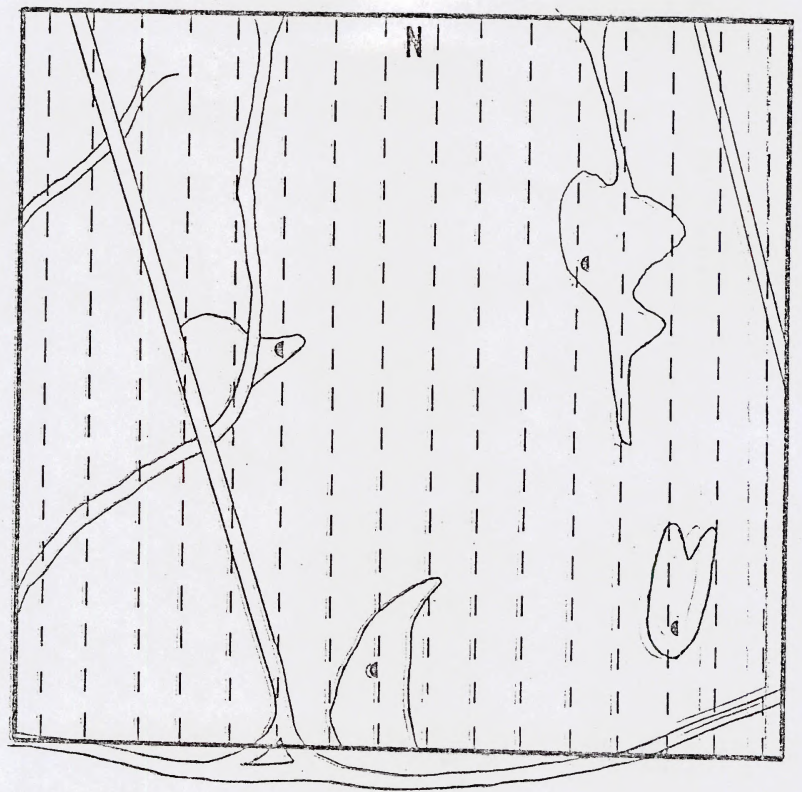

Fig. 9. Out]ine map of intensive study site number 4. No active oil developnent occurred on this site; the half-solid circles incicate old, inactive oil and gas structures on this site. 



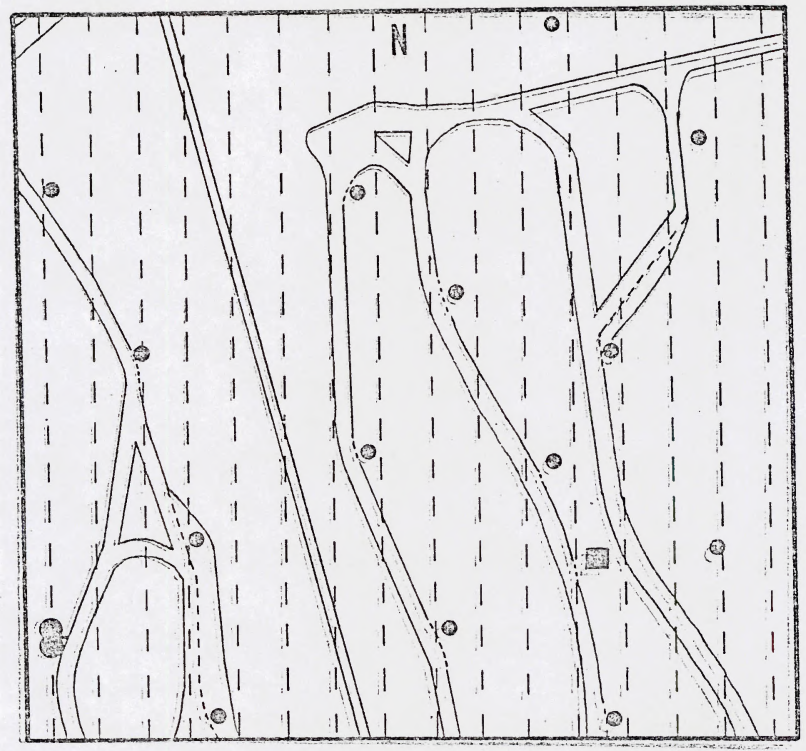

Fig. 11. Qutline map of intensive study site number -5. This BromusSchismus grassland with scattered $\Lambda$ triplex and Hymenoclea bushes was interspersed with active oil and gas structures. Dirt roads on the area received moderate usage. 


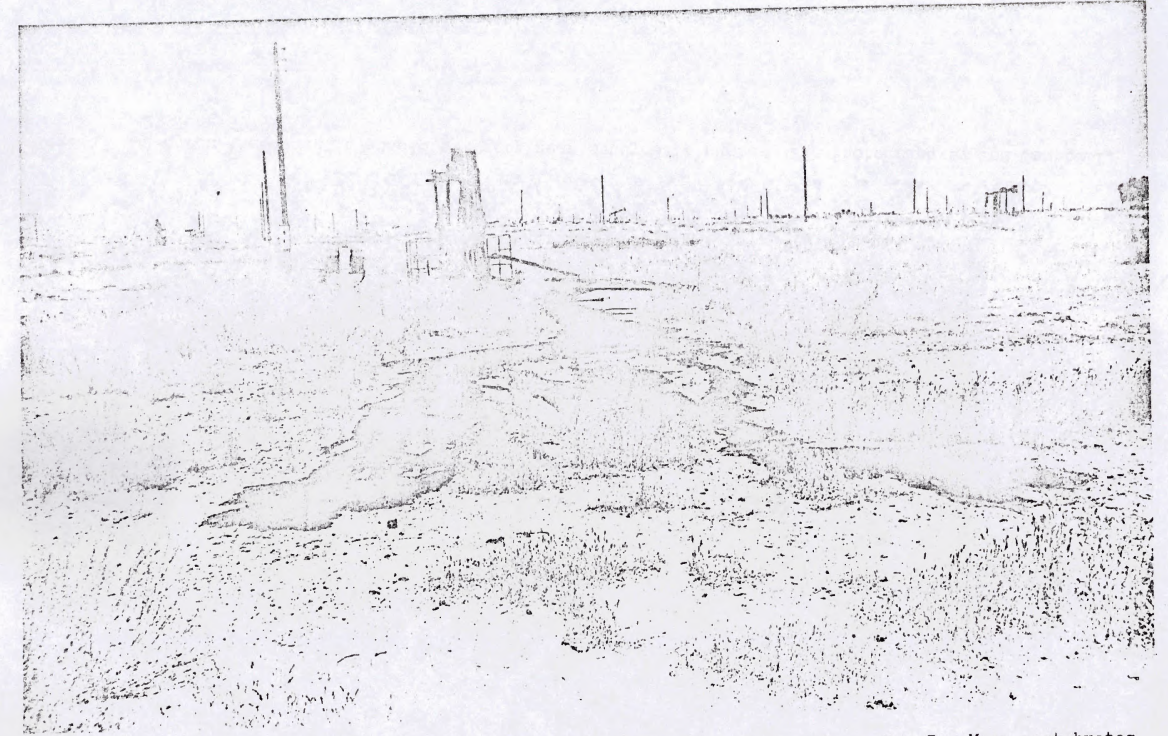

Fig: 12: Typical oil seep from an operating oil well on intensive study site number 5 . Many vertebrates were trapped in this o11. Photograph by Tom Campbe11, 20 June 1979. 


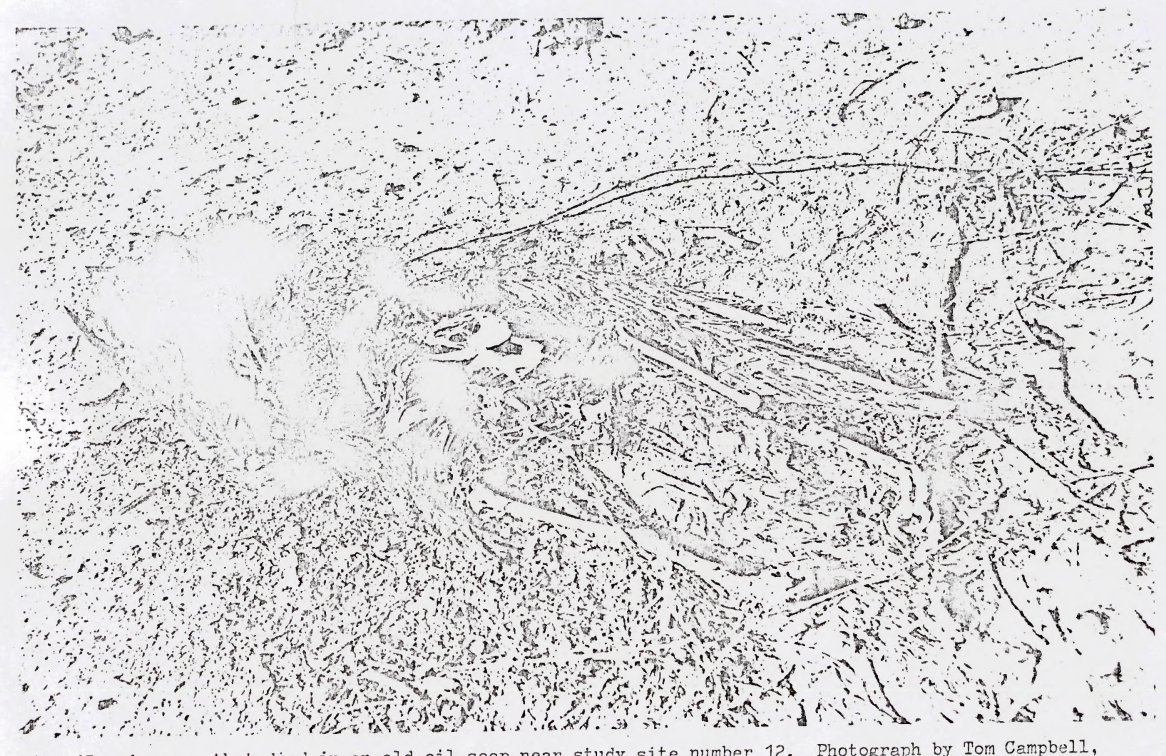

Fig. 13. A raven that died in an old oil seep near study site number 12. Photograph by Tom Campbell, 21 June 1979. 


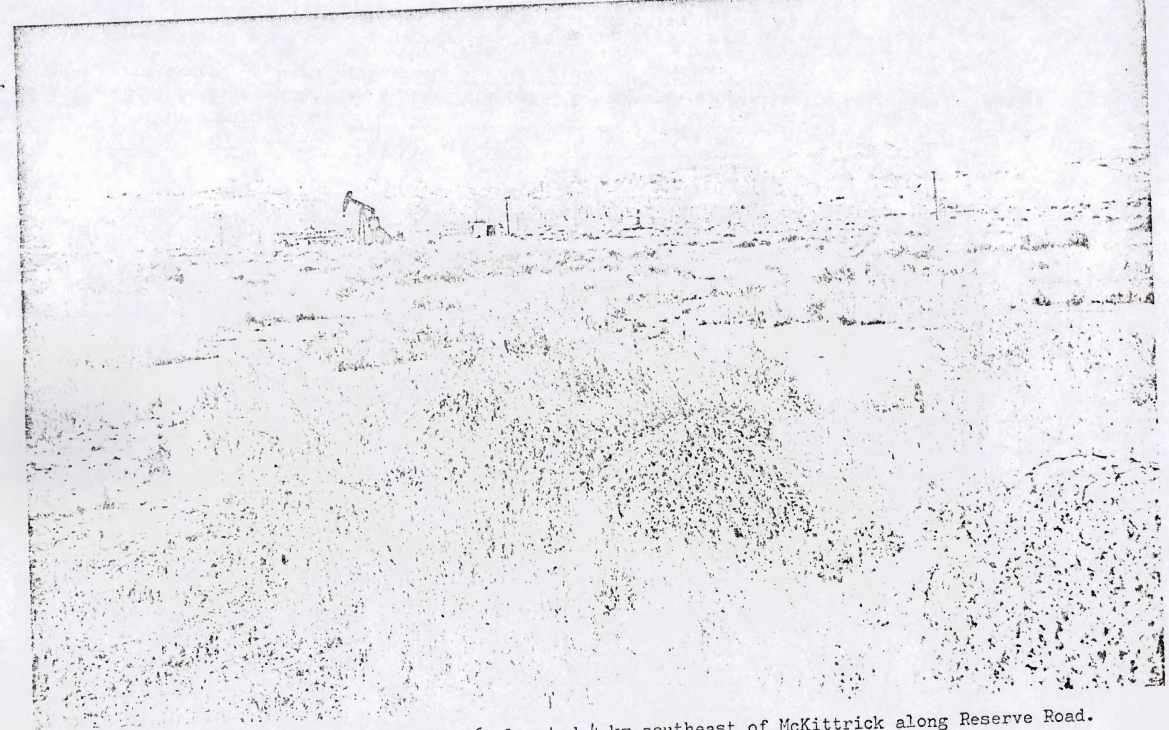

Fis. 14. Nonintensive study site number 6 , located $4 \mathrm{~km}$ southeast of McKittrick along Reserve Road. Photoraph by Jennifer Babcock, 4 July 1979. 


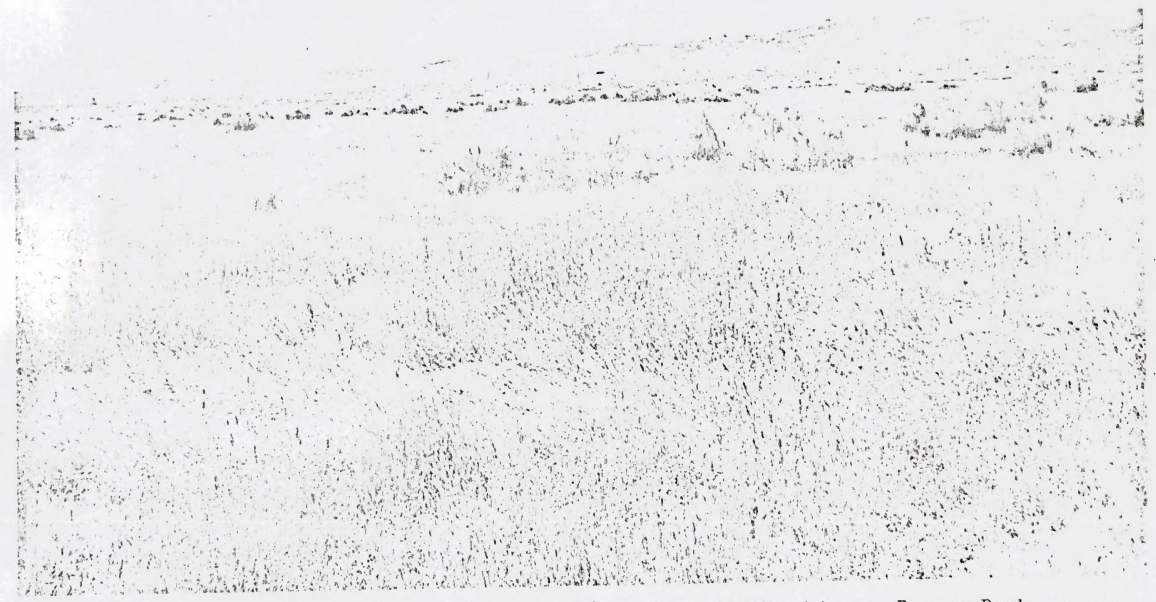

Fig. 15. Nonintensive study site number 7, located $2.4 \mathrm{~km}$ east of McKittrick near Reserve Road. Photograph by Jennifer Babcock 2 July 1979. 


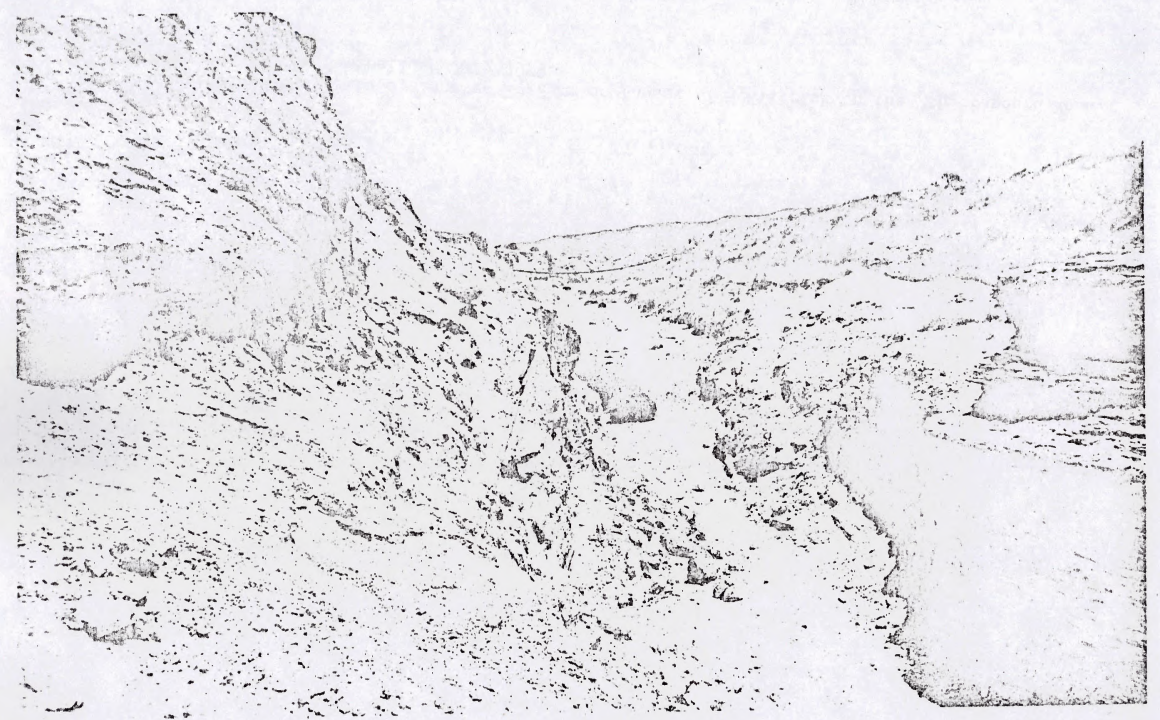

Fis: 6 : This wash ruthing throught nohintehsive study site $?$ was typical of those found on many of the study sites. Photograph by Jehnifer Babcock; ż July 1979. 


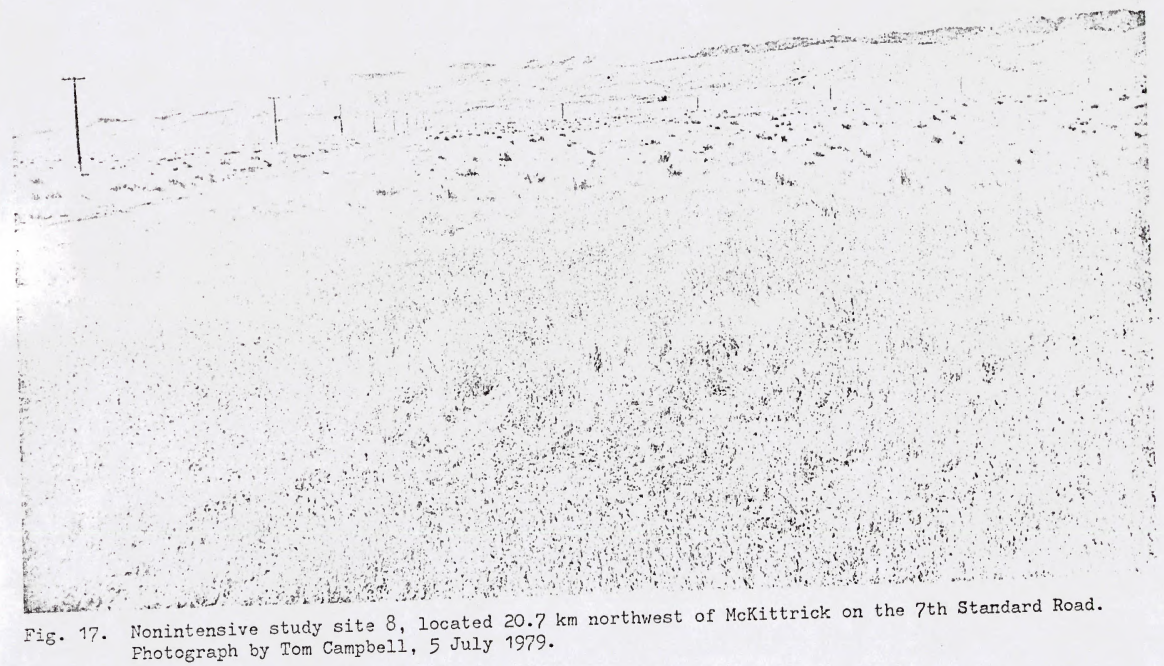




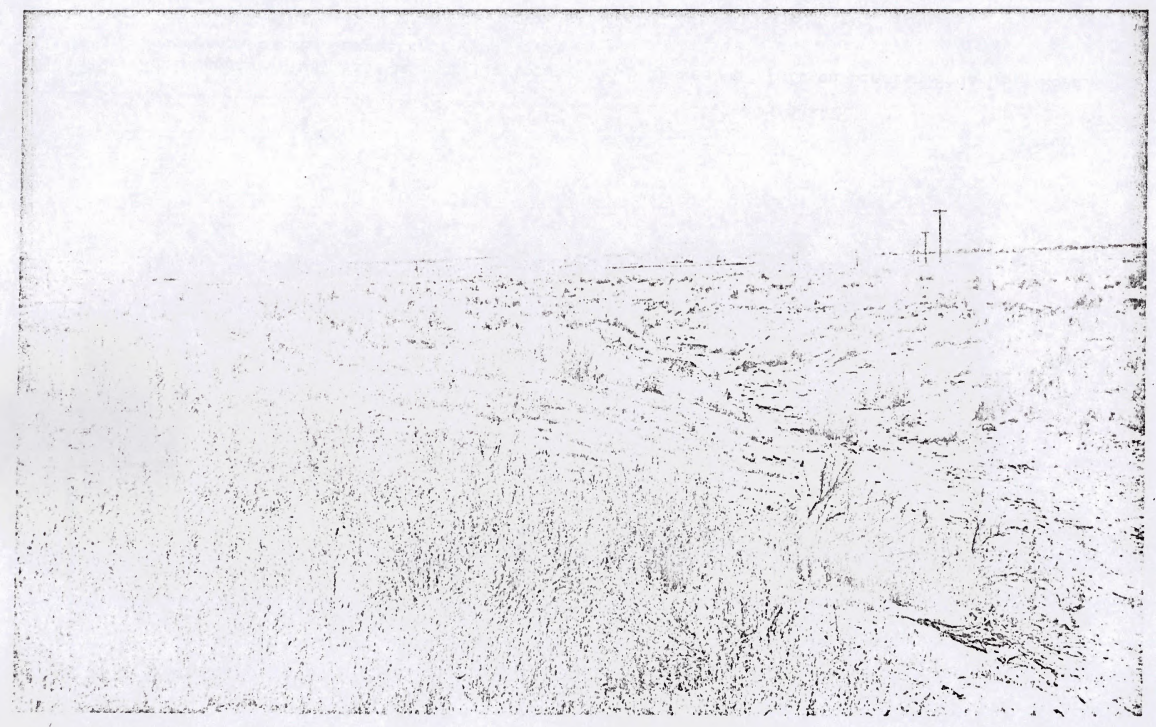

Fif. 18. Nonintensive study site number $9,-$ losated $7.2 \mathrm{~km}$ northwest of Taft on Midway Road. Photograph by Tom Campbell, 18 June 1979. 


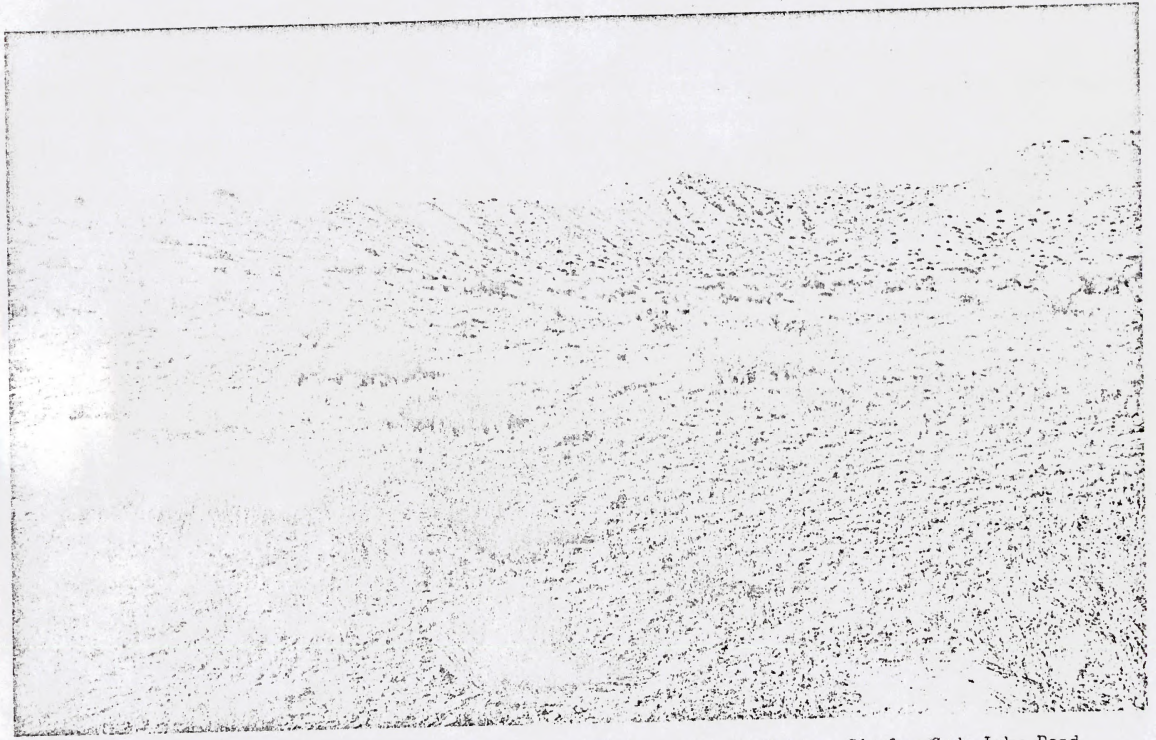

Fig. 19. Nenintensive study site mubr 10 , located $18.5 \mathrm{~km}$ west of Taft on Simmler-Soda Lake Road. Photograph by. Tom Cempbell, 9 vine 1979. 


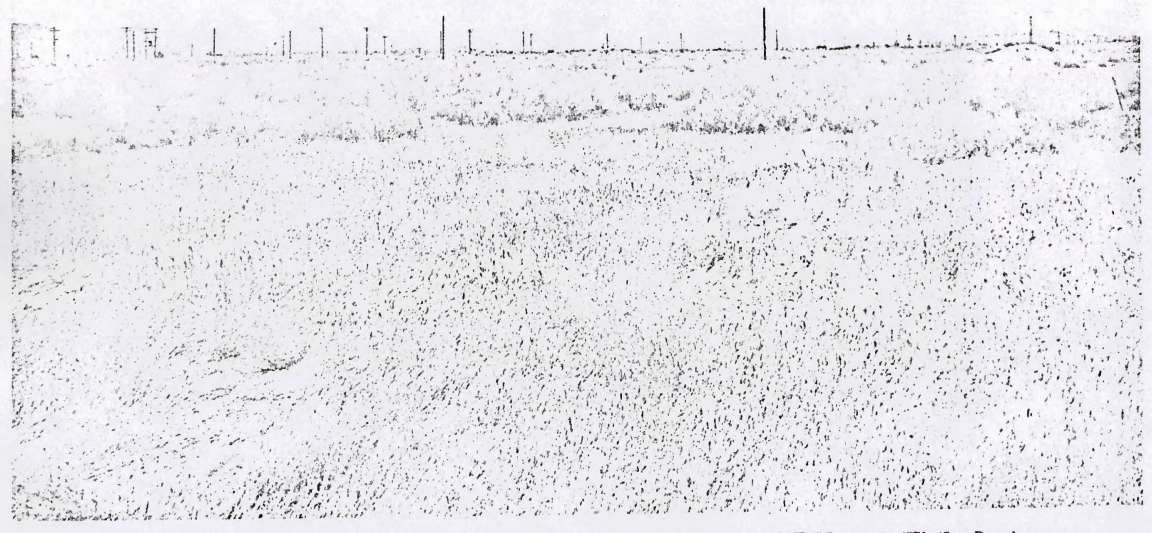

Fig. 20. Narintensive study site number 11, located $3.7 \mathrm{~km}$ northwest of:Fellows on Shale Road. Photograph by Steve Juarez, 18 June 1979. 


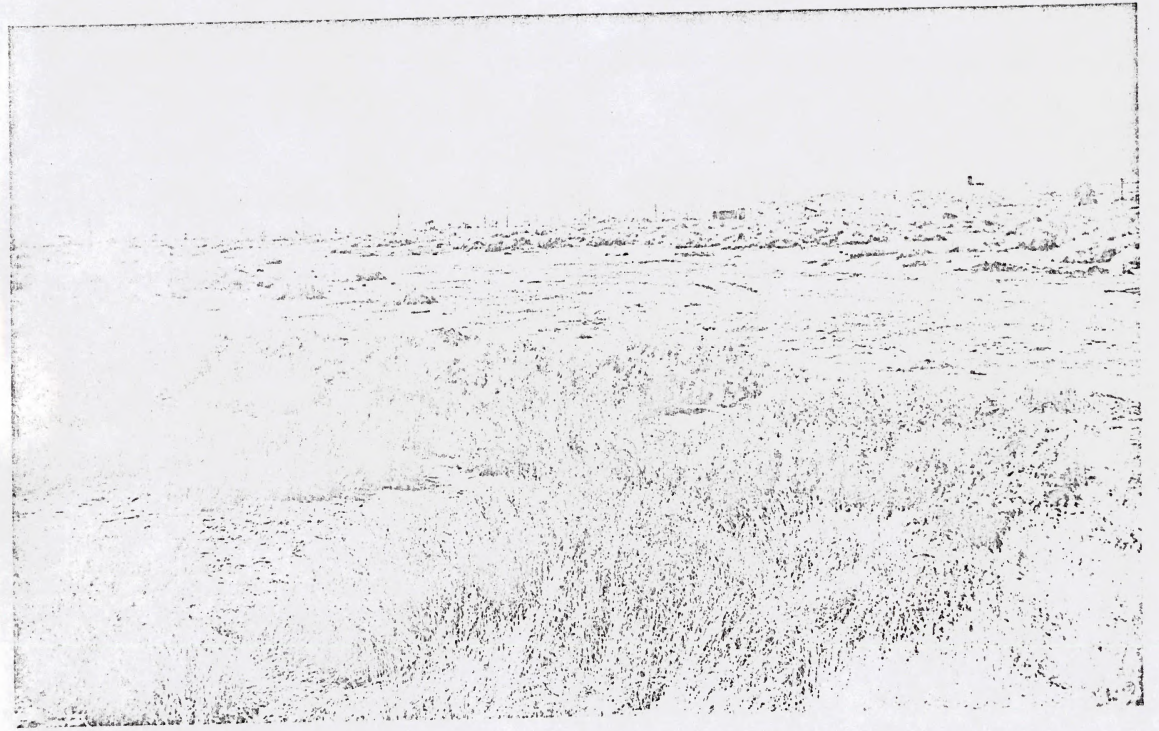

Fig. 21. Nonintensive study site numbèr 12, located $4 \mathrm{~km}$ northeast of Maricopa near Kerto Road. Photofraph by Ton.Cempil. 2 June 1979. 


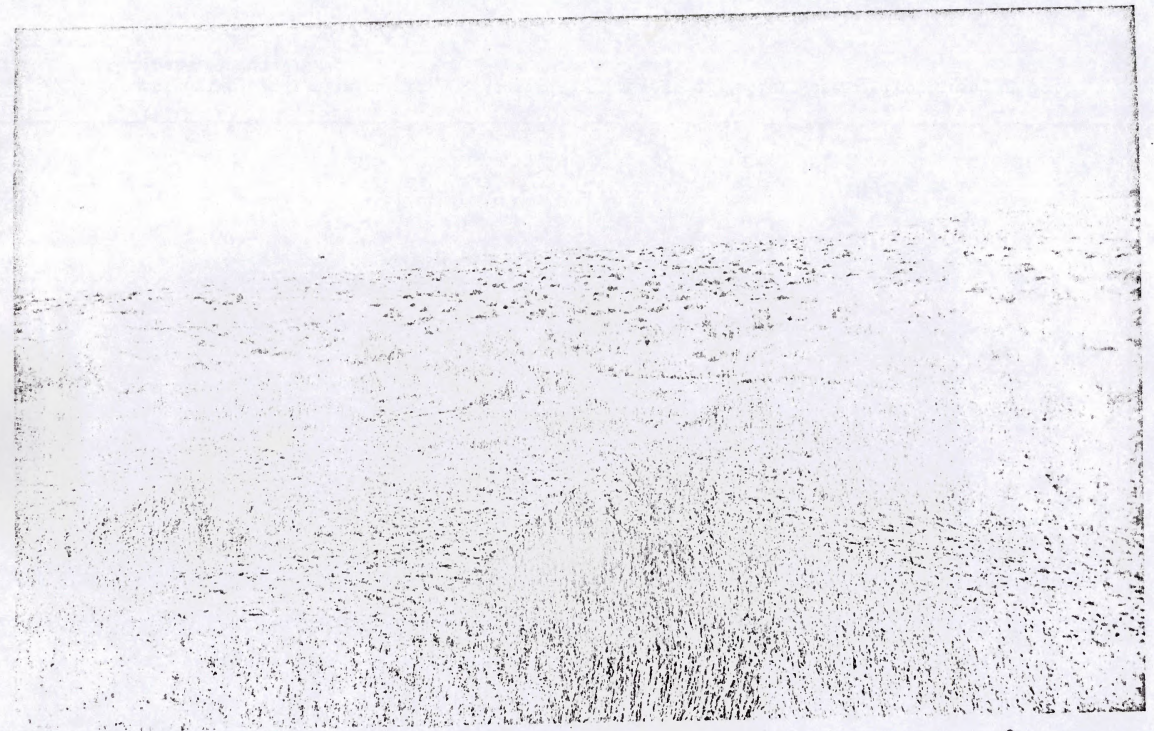

Fis. 22. Nonintensive study site 13, located $4 \mathrm{~km}$ north-northeast of McKittrish on Highway 58. Photograph by Tom Campbell, 18 June 1979. 


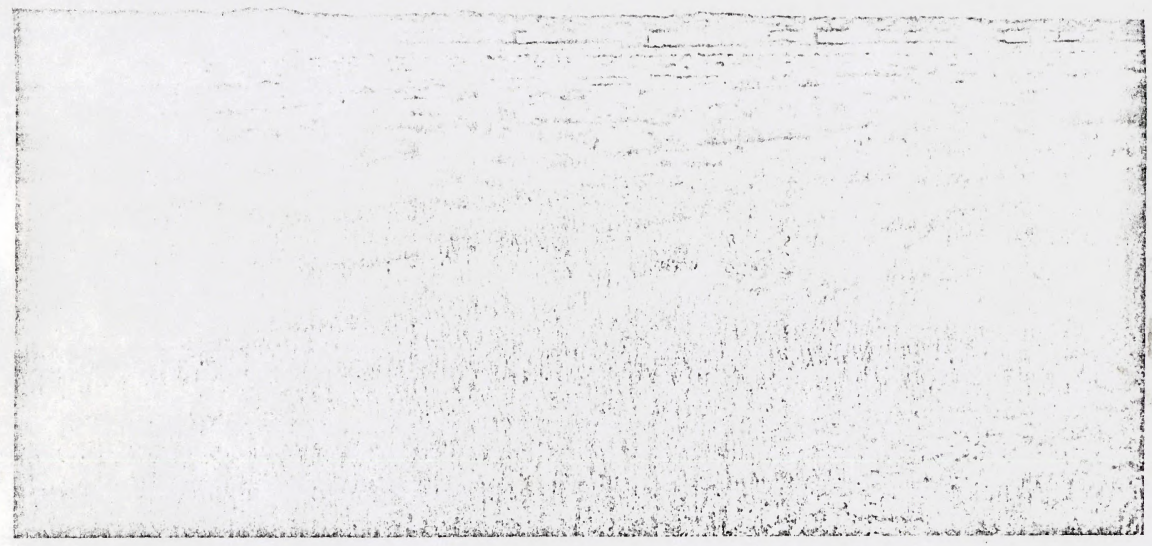

F.z. 23, Nonintensive study Eite number 14 , located. $3.8 \mathrm{~km}$ west of Valley Acres. Photograpl by Tom Campbe11, 1 June 1979. 